\title{
Nucleus-Independent Chemical Shift (NICS) as a Criterion for the Design of New Antifungal Benzofuranones
}

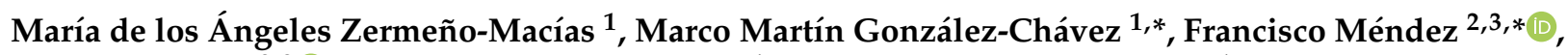 \\ Arlette Richaud ${ }^{2,3}{ }^{\mathbb{D}}$, Rodolfo González-Chávez ${ }^{1}$, Luis Enrique Ojeda-Fuentes ${ }^{1}$, Perla del Carmen Niño-Moreno ${ }^{4}$ \\ and Roberto Martínez ${ }^{5}$
}

check for updates

Citation: Zermeño-Macías, M.d.l.Á.; González-Chávez, M.M.; Méndez, F.; Richaud, A.; González-Chávez, R.; Ojeda-Fuentes, L.E.; Niño-Moreno, P.d.C.; Martínez, R.

Nucleus-Independent Chemical Shift (NICS) as a Criterion for the Design of New Antifungal Benzofuranones. Molecules 2021, 26, 5078. https:// doi.org/10.3390/molecules26165078

Academic Editors: Carlo Gatti,

Maxim L. Kuznetsov, David

L. Cooper and Miroslav Kohout

Received: 30 July 2021

Accepted: 17 August 2021

Published: 21 August 2021

Publisher's Note: MDPI stays neutral with regard to jurisdictional claims in published maps and institutional affiliations.

Copyright: (c) 2021 by the authors. Licensee MDPI, Basel, Switzerland. This article is an open access article distributed under the terms and conditions of the Creative Commons Attribution (CC BY) license (https:// creativecommons.org/licenses/by/ $4.0 /)$.
1 Facultad de Ciencias Químicas, Universidad Autónoma de San Luis Potosí, Av. Dr. Manuel Nava No. 6 Zona Universitaria, San Luis Potosí 78210, Mexico; angeles.zermeno@uaslp.mx (M.d.l.Á.Z.-M.); rodolfo.gonzalez@uaslp.mx (R.G.-C.); luisenrique.ojedaf@yahoo.com.mx (L.E.O.-F.)

2 Departamento de Química, División de Ciencias Biológicas e Ingeniería, Universidad Autónoma Metropolitana, Unidad Iztapalapa, Ciudad de México 09340, Mexico; avrt@xanum.uam.mx

3 CEMHTI-CNRS, UPR3079, Site Haute Température, CS 90055, 1D avenue de la Recherche Scientifique, CEDEX 2, 45071 Orléans, France

4 Centro de Investigación en Ciencias de la Salud y Biomedicina (CICSaB), UASLP. Av. Paseo de los Derechos Humanos No. 300, Lomas de San Luis, San Luis Potosí 78210, Mexico; ncarmenp@uaslp.mx

5 Instituto de Química, Universidad Nacional Autónoma de México, Circuito Exterior de Ciudad Universitaria, Ciudad de México 04510, Mexico; robmar@servidor.unam.mx

* Correspondence: gcmm@uaslp.mx (M.M.G.-C.); fm@xanum.uam.mx (F.M.); Tel.: +2-444-8262300 (ext. 6471) (M.M.G.-C.); +52-555-804-6400 (ext. 3326) (F.M.)

Abstract: The assertion made by Wu et al. that aromaticity may have considerable implications for molecular design motivated us to use nucleus-independent chemical shifts (NICS) as an aromaticity criterion to evaluate the antifungal activity of two series of indol-4-ones. A linear regression analysis of NICS and antifungal activity showed that both tested variables were significantly related $(p<0.05)$; when aromaticity increased, the antifungal activity decreased for series I and increased for series II. To verify the validity of the obtained equations, a new set of 44 benzofuran-4-ones was designed by replacing the nitrogen atom of the five-membered ring with oxygen in indol-4ones. The NICS(0) and NICS(1) of benzofuran-4-ones were calculated and used to predict their biological activities using the previous equations. A set of 10 benzofuran-4-ones was synthesized and tested in eight human pathogenic fungi, showing the validity of the equations. The minimum inhibitory concentration (MIC) in yeasts was $31.25 \mu \mathrm{g} \cdot \mathrm{mL}^{-1}$ for Candida glabrata, Candida krusei and Candida guilliermondii with compounds 15-32, 15-15 and 15-1. The MIC for filamentous fungi was $1.95 \mu \mathrm{g} \cdot \mathrm{mL}^{-1}$ for Aspergillus niger for compounds 15-1, 15-33 and 15-34. The results obtained support the use of NICS in the molecular design of compounds with antifungal activity.

Keywords: NICS; aromaticity; benzofuran-4-one; antifungal activity; quantitative structure-activity relationship

\section{Introduction}

Aromaticity began as a descriptor of the special stability of benzene. In 1933, Pauling and Wheland found that the resonance between the Kekulé (the most important), Dewar, Claus and Armstrong-Baeyer structures imparts to benzene its peculiar aromatic properties [1]. In 1993, Schleyer et al. developed nucleus-independent chemical shifts (NICS) as an aromaticity criterion [2]. The NICS have been widely used in the study of annulenes, polycyclic aromatic hydrocarbons, hydrocarbon pericyclic reaction transition states, $\sigma$-aromaticity / $\sigma$-antiaromaticity, Möbius aromaticity [3], the relationship between bond dissociation enthalpy and the antioxidant activity [4]. 
In 2014, Wu et al. suggested that aromaticity may have considerable implications for molecular design [5]. They investigated hydrogen bonding-aromaticity relationships for different H-bonded substrates and concluded that "such relationships may have considerable implications for molecular design, as the functions of many heterocyclic biomolecules and drugs rely on the binding via H-bonds of a dominant keto/imine or enol/amine tautomer" [5]. The proposal should be very useful for the synthesis of biologically active compounds that have aromatic moieties in their structure, for example, the biologically active aromatic compounds that constitute an important group of drugs widely used in various medicinal applications [6]. However, to the best of our knowledge, there is no evidence for the use of NICS in the experimental design of aromatic compounds with biological activity, especially with antifungal properties.

Recently, antifungal activity has acquired great importance due to the increasing rates of occurrence and mortality as a result of opportunistic mycosis caused by species of Aspergillus, Candida, Coccidioides, Cryptococcus and Histoplasma [7]. Different kinds of antifungal compounds have been used as therapeutic options for the treatment of systemic fungal infections. Those drugs have disadvantages regarding high toxicity, different activity spectrums, safety in their administration and a variety of pharmacokinetic properties. Actually, some etiological agents have developed resistance by different mechanisms of action [8-10], reinforcing the studies to develop new antifungal agents [11-21].

As part of our continuing interest in the design of non-coordinating indolones as potential inhibitors for lanosterol 14- $\alpha$-demethylase (CYP51), we synthesized two series of indol-4-ones that showed antifungal activity against Aspergillus (filamentous) and Candida (yeast) fungi (Figure 1). The docking study suggested that the antifungal activity of indol-4one increases when its keto moiety increases the capacity to form a hydrogen bond with the Arg96 residue of Mycobacterium tuberculosis CYP51 [22]. Molecular electrostatic potential surfaces and Fukui functions suggested that there is a correlation between the antifungal activity and the electrophilic/nucleophilic character of the keto/pyrrole moieties and the polarity of indol-4-ones [23]. In this work, we calculated the NICS(0) and NICS(1) of indol4-ones; a linear regression analysis showed that when aromaticity increased, the antifungal activity decreased for series I and increased for series II. As a way to use the obtained equations and test the statement of $\mathrm{Wu}$, Jackson and Schleyer, we designed a new set of 44 benzofuran-4-ones by replacing the pyrrole ring with furan in indol-4-ones (replacing the nitrogen atom with oxygen in the five-membered ring). The 10 most promising molecules were synthesized and tested against eight human pathogenic fungi. The statistical analysis of the NICS values and the antifungal activity of the 10 benzofuran-4-ones followed the expected trend, showing the validity of the statement of $\mathrm{Wu}$ et al.<smiles>Cc1cc2c([nH]1)CC(C)(C)CC2=O</smiles>

6<smiles>[X]c1ccc(-n2c(C)cc3c2CC(C)(C)CC3=O)cc1</smiles>

7 a-g

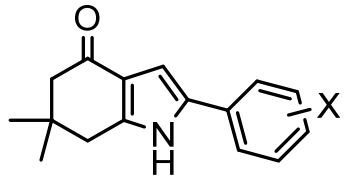

8 a-g

Figure 1. Indol-4-ones 6, 7a-g and 8a-g $(\mathrm{X}: \mathrm{a}=\mathrm{H}, \mathrm{b}=2-\mathrm{F}, \mathrm{c}=4-\mathrm{F}, \mathrm{d}=2,4-\mathrm{diF}, \mathrm{e}=2-\mathrm{Cl}, \mathrm{f}=4-\mathrm{Cl}$, $\mathrm{g}=2,4-\mathrm{diCl})$. We used the original numbering of the compounds that were synthesized in [22].

\section{Results and Discussion}

\subsection{NICS(0) and NICS(1) of Indol-4-ones}

Table 1 shows the calculated aromaticity values for the five-membered ring (pyrrole ring) of the set of 15 indol-4-ones. The trends of the NICS(0) values for series I and II are $6>7 f>7 c>7 g>7 d>7 e>7 a>7 b$ and $8 g>8 e>8 d>8 c>8 f>8 a>8 b$, while the trends of the NICS(1) values for series I and II are $6>7 f>7 c>7 d=7 b>7 e>7 a>7 g$, 
and $\mathbf{8 g}>\mathbf{8 e}>\mathbf{8 c}>\mathbf{8 d}>\mathbf{8 f}>\mathbf{8 b}>\mathbf{8 a}$. We can observe for the unsubstituted molecule 6 that the replacement of the $\mathrm{H}$ atom in the $\mathrm{NH}$ or $\mathrm{CH}_{3}$ moiety by a phenyl group (7a or 8a) decreases its aromaticity (except for $\mathbf{8 e}$ and $\mathbf{8 g}$ ). The additional substitution of the $\mathrm{H}$ atom in the phenyl ring of $7 \mathrm{a}$ and $8 \mathrm{a}$ by $X$ causes the aromaticity of series $I(7 \mathbf{a}-7 \mathrm{~g})$ to be less than that of series II $(\mathbf{8 a}-\mathbf{8 g})$. The substitution of the $\mathrm{H}$ atom in the phenyl ring with fluorine at position $2(\mathbf{7 b}$ and $\mathbf{8 b})$ greatly reduces the aromaticity $(\mathrm{NICS}(0))$ while the effect of substitution with chlorine in position 2 (8e) and disubstitution in positions 2 and $4(8 \mathbf{g})$ increases the aromaticity.

Table 1. NICS values for 15 indol-4-ones.<smiles>Cc1cc2c([nH]1)CC(C)(C)CC2=O</smiles>

6<smiles>[X]c1ccc(-n2c(C)cc3c2CC(C)(C)CC3=O)cc1</smiles>

7 a-g

\begin{tabular}{ccccc} 
& Compound & $\mathrm{R}$ & $\begin{array}{c}\mathrm{NICS}(0), \\
\mathrm{ppm}\end{array}$ & $\begin{array}{c}\text { NICS(1), } \\
\text { ppm }\end{array}$ \\
\hline $\mathbf{S}$ & $\mathbf{6}$ & - & -10.34 & -7.67 \\
$\mathbf{E}$ & $\mathbf{7 a}$ & $\mathrm{H}$ & -9.80 & -6.08 \\
$\mathbf{R}$ & $\mathbf{7 b}$ & $2-\mathrm{F}$ & -9.71 & -6.37 \\
$\mathbf{I}$ & $\mathbf{7 c}$ & $4-\mathrm{F}$ & -10.14 & -7.07 \\
$\mathbf{E}$ & $\mathbf{7 d}$ & $2,4-\mathrm{diF}$ & -9.90 & -6.37 \\
$\mathbf{S}$ & $\mathbf{7 e}$ & $2-\mathrm{Cl}$ & -9.83 & -6.09 \\
& $\mathbf{7 f}$ & $4-\mathrm{Cl}$ & -10.17 & -7.25 \\
$\mathbf{I}$ & $\mathbf{7 g}$ & $2,4-\mathrm{diCl}$ & -9.93 & -5.73 \\
$\mathbf{S}$ & $\mathbf{8 a}$ & $\mathrm{H}$ & -9.88 & -6.79 \\
$\mathbf{E}$ & $\mathbf{8 b}$ & $2-\mathrm{F}$ & -9.74 & -6.94 \\
$\mathbf{R}$ & $\mathbf{8 c}$ & $4-\mathrm{F}$ & -10.03 & -7.08 \\
$\mathbf{I}$ & $\mathbf{8 d}$ & $2,4-\mathrm{diF}$ & -10.06 & -7.03 \\
$\mathbf{E}$ & $\mathbf{8 e}$ & $2-\mathrm{Cl}$ & -10.65 & -7.29 \\
$\mathbf{S}$ & $\mathbf{8 f}$ & $4-\mathrm{Cl}$ & -9.93 & -6.95 \\
& $\mathbf{8 g}$ & $2,4-\mathrm{diCl}$ & -10.78 & -7.39 \\
$\mathbf{I I}$ & & & & \\
\hline
\end{tabular}

\subsection{Structure-Activity Relationship: Aromaticity vs. Antifungal Activity}

Simple linear regression analysis of the antifungal activity of the two series of 15 indol4-ones and their NICS(0) and NICS(1) values was conducted. The antifungal activity measured as the minimum inhibitory concentration (MIC) values against Aspergillus (filamentous) and Candida (yeast) fungi were taken from our previous report [22]. Table 2 shows the Pearson $(p)$ and sample $(r)$ correlation coefficients. For series I, good correlation values were obtained $(p<0.05)$ for the filamentous fungi Aspergillus niger (evaluated at $48 \mathrm{~h}$ ): NICS(0), $p=0.002, r=0.94 ; \mathrm{NICS}(1), p=0.001, r=0.95 ;$ Aspergillus niger (evaluated at $72 \mathrm{~h}$ ): NICS(0), $p=0.015, r=0.89 ; \mathrm{NICS}(1), p=0.068, r=0.78$, Aspergillus fumigatus (evaluated at $48 \mathrm{~h}$ ): NICS(0), $p=0.024, r=0.77$; and Aspergillus fumigatus (evaluated at $72 \mathrm{~h}$ ): NICS(0), $p=0.004, r=0.88$, NICS(1), $p=0.002, r=0.91$. We observed a major biological activity for filamentous fungi with compounds of series I [22]. Series I showed an inverse proportional relationship between both variables (see Table S1): the antifungal activity increased when the aromaticity of the pyrrole ring decreased. 
Table 2. Pearson and determination coefficients for simple linear regression NICS(0) and NICS(1) for series I: compounds 6 and $7 \mathrm{~g}$.

\begin{tabular}{|c|c|c|c|c|c|c|c|}
\hline & & 6 & & 7 a- & & & \\
\hline \multirow{2}{*}{ Microorganism } & \multirow{2}{*}{$\begin{array}{c}\text { Time of } \\
\text { Testing (h) }\end{array}$} & \multicolumn{4}{|c|}{$\operatorname{NICS}(0)$} & \multicolumn{2}{|c|}{ NICS(1) } \\
\hline & & $r$ & $r^{2}$ & $p$ & $r$ & $r^{2}$ & $p$ \\
\hline \multirow[b]{2}{*}{ C. albicans } & 24 & 0.70 & 0.49 & 0.050 * & 0.62 & 0.38 & 0.101 \\
\hline & 48 & 0.37 & 0.14 & 0.367 & 0.55 & 0.30 & 0.161 \\
\hline \multirow{2}{*}{ C. glabrata } & 24 & 0.64 & 0.41 & 0.086 & 0.57 & 0.32 & 0.140 \\
\hline & 48 & 0.60 & 0.36 & 0.119 & 0.68 & 0.46 & 0.063 \\
\hline \multirow{2}{*}{ C. krusei } & 24 & 0.59 & 0.35 & 0.125 & 0.65 & 0.43 & 0.079 \\
\hline & 48 & 0.31 & 0.10 & 0.451 & 0.50 & 0.25 & 0.204 \\
\hline \multirow{2}{*}{ C. tropicalis } & 24 & 0.59 & 0.35 & 0.125 & 0.65 & 0.43 & 0.079 \\
\hline & 48 & 0.29 & 0.08 & 0.483 & 0.49 & 0.24 & 0.222 \\
\hline C. & 24 & 0.66 & 0.44 & 0.073 & 0.67 & 0.45 & 0.070 \\
\hline guilliermondii & 48 & 0.67 & 0.45 & 0.067 & 0.66 & 0.44 & 0.075 \\
\hline \multirow{2}{*}{ C. parapsilosis } & 24 & 0.24 & 0.06 & 0.561 & 0.49 & 0.24 & 0.218 \\
\hline & 48 & 0.32 & 0.10 & 0.44 & 0.04 & 0.002 & 0.927 \\
\hline \multirow{2}{*}{ A. niger } & 48 & 0.94 & 0.89 & $0.002 *$ & 0.95 & 0.90 & 0.001 * \\
\hline & 72 & 0.89 & 0.80 & 0.015 * & 0.78 & 0.61 & $0.068^{*}$ \\
\hline \multirow{2}{*}{ A. fumigatus } & 48 & 0.77 & 0.60 & 0.024 * & 0.59 & 0.35 & 0.123 \\
\hline & 72 & 0.88 & 0.77 & 0.004 * & 0.91 & 0.83 & $0.002 *$ \\
\hline
\end{tabular}

* Statistically significant values with good data of Pearson and determination coefficients. Pearson coefficients are given in absolute values.

For series II (see Table 3), the statically significant values were obtained for the yeast fungi Candida albicans (evaluated at $48 \mathrm{~h}$ ): NICS(0), $p=0.050, r=0.75$; NICS(1), $p=0.021, r=0.83$; Candida glabrata (evaluated at $24 \mathrm{~h}$ ): NICS(0), $p=0.050, r=0.75 ; \mathrm{NICS}(1)$, $p=0.021, r=0.83$; Candida tropicalis (evaluated at $48 \mathrm{~h}$ ): NICS(1), $p=0.029, r=0.81$; and Candida parapsilosis (evaluated at $24 \mathrm{~h}$ ): $\mathrm{NICS}(0), p=0.004, r=0.91, \mathrm{NICS}(1), p=0.025$, $r=0.82$. We observed major biological activity for yeasts with compounds of series II [22]. Series II showed a direct proportional relationship between both variables (see Table S2): the antifungal activity increased when the aromaticity of the pyrrole ring increased.

\subsection{Design of New Compounds}

The linear regression analysis showed the importance of the pyrrole ring (five-membered ring) aromaticity in the activity of the indol-4-one compounds. Two significant resonance structures of indol-4-ones should be involved in the aromaticity of the pyrrole ring and biological activity (Schemes 1 and 2). The keto and enolate resonance structures are obtained by displacing the lone pair of the nitrogen atom in/out of the pyrrole ring. The aromaticity of the pyrrole ring decreases from the keto to the enolate structures because the electron density is displaced from the pyrrole ring to the oxygen atom. The antifungal activity of the indol-4-one compounds is related with the enolate resonance structure for series I and the keto resonance structure for series II. 
Table 3. Pearson and determination coefficients for simple linear regression NICS(0) and NICS(1) for series II: compounds $\mathbf{8 a}-\mathbf{g}$.<smiles>[X]c1ccc(-c2cc3c([nH]2)CC(C)(C)CC3=O)cc1</smiles>

\begin{tabular}{|c|c|c|c|c|c|c|c|}
\hline \multirow{2}{*}{ Microorganism } & \multirow{2}{*}{$\begin{array}{c}\text { Time of } \\
\text { Testing (h) }\end{array}$} & \multicolumn{3}{|c|}{$\operatorname{NICS}(0)$} & \multicolumn{3}{|c|}{ NICS(1) } \\
\hline & & $r$ & $r^{2}$ & $p$ & $r$ & $r^{2}$ & $p$ \\
\hline \multirow{2}{*}{ C. albicans } & 24 & 0.54 & 0.29 & 0.22 & 0.72 & 0.51 & 0.071 \\
\hline & 48 & 0.75 & 0.56 & 0.050 * & 0.83 & 0.69 & 0.021 * \\
\hline \multirow{2}{*}{ C. glabrata } & 24 & 0.75 & 0.56 & 0.050 * & 0.83 & 0.69 & 0.021 * \\
\hline & 48 & 0.33 & 0.11 & 0.468 & 0.60 & 0.36 & 0.151 \\
\hline \multirow{2}{*}{ C. krusei } & 24 & 0.62 & 0.39 & 0.134 & 0.72 & 0.51 & 0.071 \\
\hline & 48 & 0.62 & 0.39 & 0.134 & 0.72 & 0.51 & 0.071 \\
\hline \multirow{2}{*}{ C. tropicalis } & 24 & 0.62 & 0.39 & 0.134 & 0.72 & 0,51 & 0.071 \\
\hline & 48 & 0.73 & 0.53 & 0.064 & 0.81 & 0.65 & 0.029 * \\
\hline C. & 24 & 0.62 & 0.39 & 0.134 & 0.72 & 0.51 & 0.071 \\
\hline guilliermondii & 48 & 0.56 & 0.32 & 0.187 & 0.74 & 0.54 & 0.059 \\
\hline \multirow{2}{*}{ C. parapsilosis } & 24 & 0.91 & 0.83 & 0.004 * & 0.82 & 0.67 & 0.025 * \\
\hline & 48 & 0.032 & 0.001 & 0.945 & 0.22 & 0.05 & 0.64 \\
\hline
\end{tabular}

* Statistically significant values with good data of Pearson and determination coefficients. Pearson coefficients are given in absolute values.

\section{SERIES I}

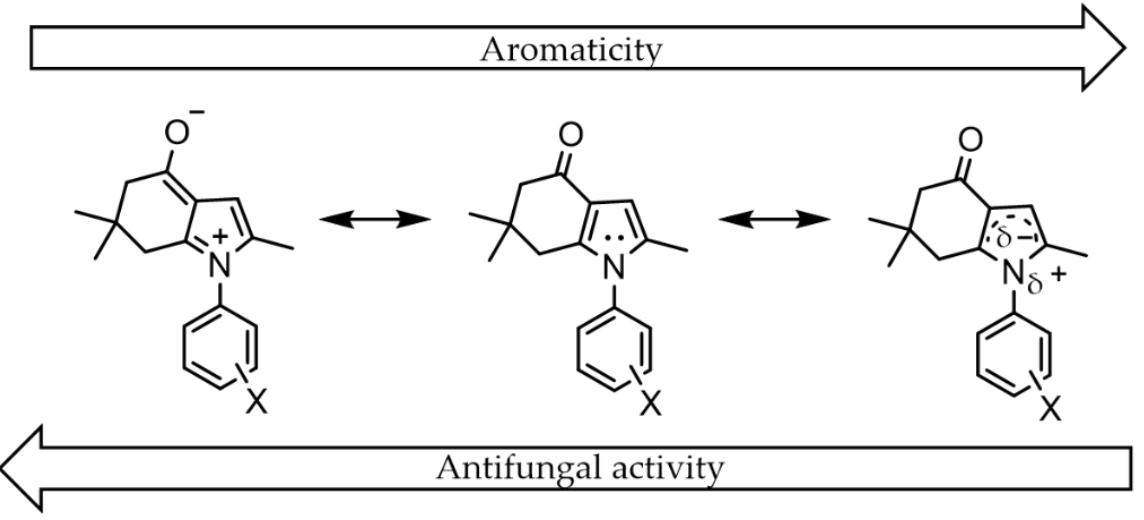

Scheme 1. Trend for the antifungal activity of indol-4-ones for series I ( 6 and $\mathbf{7 a}-\mathbf{g})$ vs. NICS(0) and NICS(1). Enolate and keto resonance structures.

To extrapolate the previous linear regression equations for aromaticity and antifungal activity, we made a bioisosteric change in the five-membered ring of indol-4-ones substituting the nitrogen atom with an oxygen atom to obtain benzofuran-4-ones. Replacement of the pyrrole ring with furan decreases the aromaticity of indol-4-ones since the furan ring is less aromatic than the pyrrole ring [24]. Therefore, a new set of benzofuran-4-ones (14, 15-1 to 15-43) was designed and the NICS(0) and NICS(1) were calculated, and as we expected, benzofuran-4-ones had lower aromaticity values than indol-4-ones. Table 4 shows that the NICS(0) and NICS(1) values ranged from -7.82 to $-8.97 \mathrm{ppm}$ and from -5.62 to $-7.92 \mathrm{ppm}$, respectively. We observed for the unsubstituted benzofuran-4-one 14 that the replacement of the $\mathrm{H}$ atom in the $\mathrm{CH}_{3}$ moiety by a phenyl group (15-1) decreased its aromaticity. The additional substitution of the $\mathrm{H}$ atom in the phenyl ring of 15-1 with $\mathrm{R}$ caused the aromaticity (measured in terms of NICS(0)) to decrease for $\mathrm{R}=4-\mathrm{OCF}_{3}(\mathbf{1 5 - 2 5})$ and increase for $\mathrm{R}=2-\mathrm{CF}_{3}$ (15-35), while for NICS(1), the aromaticity decreased for $\mathrm{R}=4$-Phe (15-28) 
and increased for $\mathrm{R}=2-\mathrm{NO}_{2}$ (15-28). Therefore, the aromaticity for benzofuran-4-ones decreased and increased with electron-donating and electron-withdrawing substituents.

\section{SERIES II}
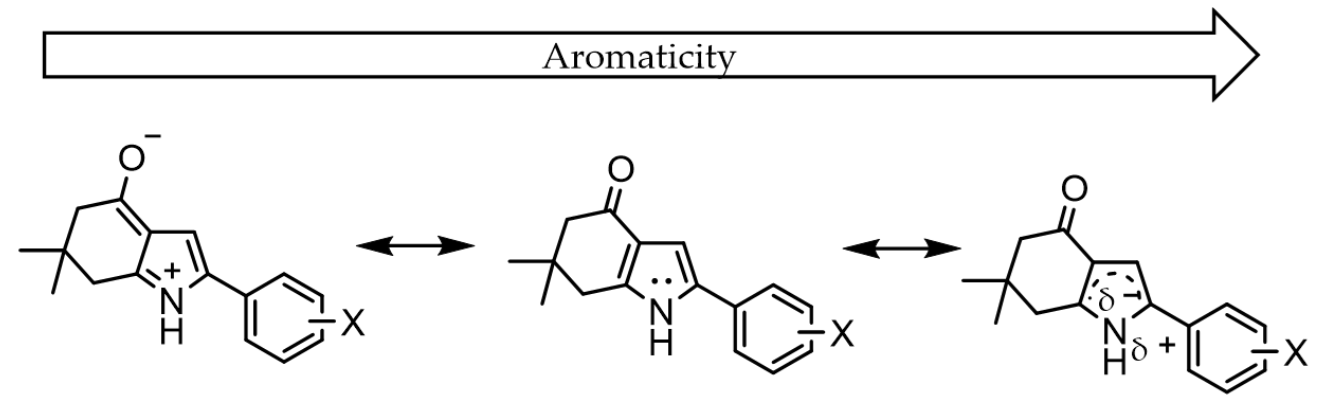

Antifungal activity

Scheme 2. Trend for the antifungal activity of indol-4-ones for series II (8a-g) vs. NICS(0) and NICS(1). The enolate and keto resonance structures.

Once the antifungal activity of benzofuran-4-ones was interpolated using the equations obtained in the linear regression analysis with indol-4-ones (Tables S1 and S2 in supplementary) and the NICS(0) and NICS(1) values (Table 4), some of the proposed benzofuran-4-ones were synthesized to corroborate the theoretical prediction. The criteria used to select the benzofuran-4-ones to be synthesized were as follows: (a) series of compounds that could exhibit high, intermediate and low calculated antifungal activity based on the interpolation; (b) compounds that influenced the calculated activity of different yeasts or filamentous fungi; (c) compounds the chemical structure whereof allows obtaining benzofuran-4-ones with a variety of substituents in the phenyl ring: strong/weak activators/deactivators; (d) molecules with the same groups in identical positions as in indol-4-ones for later comparisons; (e) easy access to reagents and the synthetic procedure. The benzofuran-4-ones selected were as follows: 14, 15-1, 15-3, 15-11, 15-15, 15-28, 15-32, 15-33, 15-34 and 15-41.

\subsection{Synthesis of Benzofuran-4-ones}

The synthesis of benzofuran-4-one 14 (see Scheme 3) began with preparation of the tricarbonyl compound 12 from dimedone 11 via nucleophilic substitution by chloroacetone (using EtONa as the base) under the $\mathrm{N}_{2}$ atmosphere (enolate formation) [22]. Intramolecular cyclization of $\mathbf{1 2}$ through the Paal-Knorr reaction was performed using the methodology reported by Goncalves et al. using trimethylsilyl chloride under microwave irradiation [25]. For compounds 15-1, 15-3, 15-11, 15-15, 15-28, 15-32, 15-33, 15-34 and 15-41, bromoacetophenones 10-1, 10-3, 10-11, 10-15, 10-28, 10-32, 10-33, 10-34 and 10-41 were synthetized from the R-acetophenones 9-1, 9-3, 9-11, 9-15, 9-28, 9-32, 9-33, 9-34 and 9-41 using $p$ toluensulfonic acid and $N$-bromosuccinimide (NBS). Nucleophilic substitution with the enolate of dimedone 11 (using $\mathrm{K}_{2} \mathrm{CO}_{3}$ as the base) yielded the tricarbonyl compounds 13-1, 13-3, 13-11, 13-15, 13-28, 13-32, 13-33, 13-34 and 13-41. Benzofuran-4-ones 15-1, 15-3, 15-11, 15-15, 15-28, 15-32, 15-33, 15-34 and 15-41 were obtained via Paal-Knorr reactions using trimethylsilyl chloride under microwave irradiation [25]. This methodology for obtaining furanes is free from the use of strong acids and toxic solvents and the reaction time is short; the products precipitate and generally do not require purification by chromatographic methods, which indicates tha the reaction is efficient and could be considered within the concept of green chemistry. 
Table 4. NICS values for the 44 benzofuran-4-ones designed (14, 15-1 to 15-43).

\begin{tabular}{|c|c|c|c|c|c|c|c|}
\hline & & 1 & & $15(1-43)$ & \multirow[b]{2}{*}{$\mathbf{R}$} & \multirow[b]{2}{*}{$\begin{array}{c}\text { NICS(0), } \\
\text { ppm }\end{array}$} & \multirow[b]{2}{*}{$\begin{array}{c}\text { NICS(1), } \\
\text { ppm }\end{array}$} \\
\hline Compound & $\mathbf{R}$ & $\begin{array}{c}\text { NICS(0) } \\
\text { ppm }\end{array}$ & $\begin{array}{l}\text { NICS(1) } \\
\text { ppm }\end{array}$ & Compound & & & \\
\hline 14 & - & -8.97 & -7.19 & $15-22$ & $4-\mathrm{OCH}_{2} \mathrm{OCH}_{3}$ & -8.00 & -6.40 \\
\hline $15-1$ & $\mathrm{H}$ & -8.02 & -6.24 & $15-23$ & $4-\mathrm{OCH}_{2} \mathrm{CH}_{2} \mathrm{OH}$ & -8.00 & -6.85 \\
\hline $15-2$ & $4-\mathrm{N}\left(\mathrm{C}_{4} \mathrm{H}_{8}\right)$ & -7.93 & -6.92 & $15-24$ & $3,4-\left(\mathrm{OCH}_{2} \mathrm{O}\right)$ & -7.95 & -6.99 \\
\hline $15-3$ & 4-imidazole & -7.89 & -7.24 & $15-25$ & $4-\mathrm{OCF}_{3}$ & -7.82 & -7.09 \\
\hline $15-4$ & $4-\mathrm{N}\left(\mathrm{CH}_{2} \mathrm{CH}_{3}\right)_{2}$ & -7.85 & -6.88 & $15-26$ & $4-\mathrm{SCH}_{3}$ & -7.99 & -7.05 \\
\hline $15-5$ & $4-\mathrm{N}\left(\mathrm{C}_{5} \mathrm{H}_{9} \mathrm{OH}\right)$ & -7.88 & -6.95 & $15-27$ & $4-\mathrm{C}\left(\mathrm{CH}_{3}\right)_{3}$ & -7.98 & -6.99 \\
\hline $15-6$ & $2-\mathrm{OH}$ & -8.07 & -7.01 & $15-28$ & 4-phenyl & -7.84 & -5.62 \\
\hline $15-7$ & $3-\mathrm{OH}$ & -8.09 & -6.72 & $15-29$ & 4-Cl & -8.06 & -7.01 \\
\hline $15-8$ & 4-OH & -8.04 & -6.67 & $15-30$ & 2,5-diCl & -8.30 & -7.10 \\
\hline $15-9$ & 2,4-diOH & -8.21 & -6.86 & $15-31$ & 3,4-diCl & -8.10 & -7.13 \\
\hline $15-10$ & 2,5-diOH & -8.15 & -7.16 & $15-32$ & $4-\mathrm{Cl}-3-\mathrm{NO}_{2}$ & -8.09 & -7.43 \\
\hline $15-11$ & $2-\mathrm{OCH}_{3}$ & -8.00 & -7.31 & $15-33$ & $4-\mathrm{F}$ & -8.03 & -6.80 \\
\hline $15-12$ & $3-\mathrm{OCH}_{3}$ & -7.99 & -7.04 & $15-34$ & 2,4-diF & -8.2 & -7.37 \\
\hline $15-13$ & $4-\mathrm{OCH}_{3}$ & -7.92 & -6.78 & $15-35$ & $2-\mathrm{CF}_{3}$ & -8.94 & -7.36 \\
\hline $15-14$ & $2,4-\mathrm{diOCH}_{3}$ & -8.09 & -7.19 & $15-36$ & $4-\mathrm{CF}_{3}$ & -7.96 & -7.21 \\
\hline $15-15$ & $2,5-\mathrm{diOCH}_{3}$ & -8.03 & -6.75 & $15-37$ & $2-\mathrm{COOH}$ & -8.80 & -6.76 \\
\hline $15-16$ & $3,4-\mathrm{diOCH}_{3}$ & -8.06 & -7.18 & $15-38$ & $4-\mathrm{COOH}$ & -7.96 & -6.91 \\
\hline $15-17$ & $2-\mathrm{OH}-4-\mathrm{OCH}_{3}$ & -8.14 & -6.88 & $15-39$ & $2-\mathrm{NO}_{2}$ & -8.76 & -7.92 \\
\hline $15-18$ & $2-\mathrm{OH}-5-\mathrm{OCH}_{3}$ & -8.11 & -7.02 & $15-40$ & $3-\mathrm{NO}_{2}$ & -7.96 & -6.96 \\
\hline $15-19$ & $3-\mathrm{OCH}_{3}-4-\mathrm{OH}$ & -7.93 & -6.92 & $15-41$ & $4-\mathrm{NO}_{2}$ & -7.96 & -7.42 \\
\hline $15-20$ & $3,5-\mathrm{diOCH}_{3}-4-\mathrm{OH}$ & -7.95 & -6.17 & $15-42$ & $4-\mathrm{SO}_{2} \mathrm{CH}_{3}$ & -7.99 & -7.07 \\
\hline $15-21$ & $4-\mathrm{OCO}\left(\mathrm{C}_{6} \mathrm{H}_{5}\right)$ & -8.04 & -7.24 & $15-43$ & $4-\mathrm{SO}_{2} \mathrm{Cl}$ & -8.04 & -6.91 \\
\hline
\end{tabular}

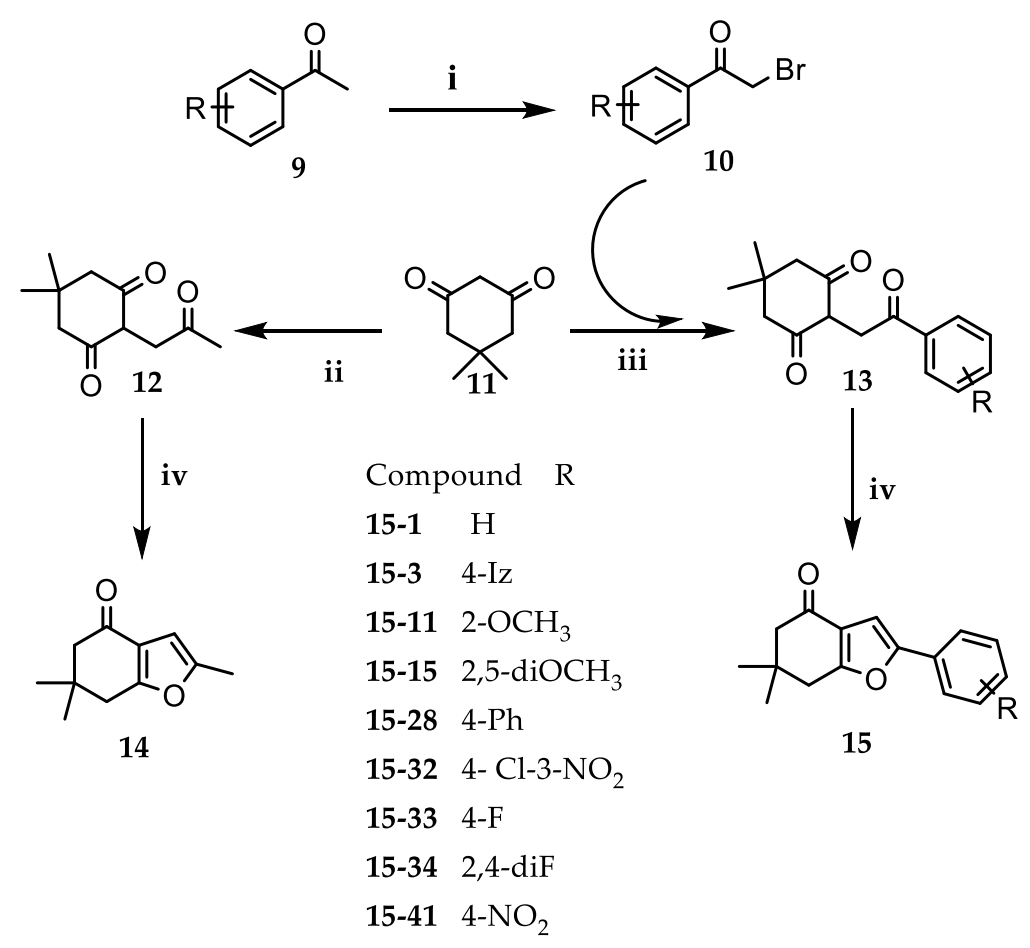

Scheme 3. Reaction conditions for the synthesis of benzofuran-4-ones. 
Reaction conditions: (i) 1 eq NBS/ 1 eq TsOH $\mathrm{H}_{2} \mathrm{O} / \mathrm{ACN} /$ reflux; (ii) 1 eq $\mathrm{ClCH}_{2} \mathrm{COCH}_{3}$ / 1 eq EtONa/EtOH $/ \mathrm{N}_{2}$ atm.; (iii) 1.8 eq $\mathrm{K}_{2} \mathrm{CO}_{3} / \mathrm{CHCl}_{3} / 12 \mathrm{~h}, \mathrm{~N}_{2}$ atm.; (iv) 1 eq $\left(\mathrm{CH}_{3}\right)_{3} \mathrm{SiCl} /$ $\mathrm{CH}_{3} \mathrm{OH} / \mathrm{MW}, 90^{\circ} \mathrm{C}, 8 \mathrm{~min}, 250 \mathrm{~W}$.

\subsection{Antifungal Activity of Benzofurans}

Table 5 shows the in vitro antifungal activities of compounds 14 and 15 . They were determined using six strains of yeast (C. albicans, C. glabrata, C. krusei, C. tropicalis, C. guilliermondii and C. parapsilosis) and two strains of fungi (A. fumigatus and A. niger). The MIC values of fluconazole and itraconazole are shown as reference antifungal drugs. The lowest and highest MIC of the yeasts were $31.25 \mu \mathrm{g} \cdot \mathrm{mL}^{-1}$ and $>500 \mu \mathrm{g} \cdot \mathrm{mL}^{-1}$. For filamentous fungi, the MIC values fluctuated between $1.95 \mu \mathrm{g} \cdot \mathrm{mL}^{-1}$ and $>500 \mu \mathrm{g} \cdot \mathrm{mL}^{-1}$. C. glabrata, C. krusei and C. guilliermondii tested at $24 \mathrm{~h}$ presented the MIC of $31.25 \mu \mathrm{g} \cdot \mathrm{mL}^{-1}$ for compounds 15-32, 15-15 and 15-1. The previous compounds had phenyl substituents acting as weak deactivators, strong activators and no substituted phenyl ring. A. niger tested at $48 \mathrm{~h}$ and $72 \mathrm{~h}$ had similar MIC values of $1.95 \mu \mathrm{g} \cdot \mathrm{mL}^{-1}$ for compounds 15-1, 15-33 and 15-34, compounds without a substituent and weak deactivators, respectively. The yeasts presented decreased antifungal activity (high MIC values) concerning fungi. In Table 6, we show the summary of NICS and MIC values of indol-4-ones and benzofuran-4ones with similar structures. Four compounds from each group had comparable moieties: 6 vs. $14,8 \mathrm{a}$ vs. $15-1,8 \mathrm{c}$ vs. $15-33$ and $8 \mathrm{~d}$ vs. $15-34$. The compound that decreased the MIC values in more species was 15-1 (four yeasts and two filamentous fungi).

The Mann-Whitey $U$ test was performed to evaluate the difference in the antifungal activity of two different kinds of compounds: indol-4-ones and benzofuran-4-ones with the same substituent $(\mathbf{6}, \mathbf{8 a}, \mathbf{8 c}, \mathbf{8 d}, \mathbf{1 4}, \mathbf{1 5 - 1}, \mathbf{1 5 - 3 3}$ and $\mathbf{1 5 - 3 4})$. The summary of the statistical results is shown in Table S-3. We found a significant variation in the antifungal activity for yeasts ( $24 \mathrm{~h}$ of testing) and filamentous fungi (48 and $72 \mathrm{~h}$ of testing) $(p<0.05)$. No significant difference was found between the antifungal activity of benzofuran-4-ones and indol-4-ones in the yeasts evaluated at $48 \mathrm{~h}(p>0.05)$. For the yeasts at $24 \mathrm{~h}$, benzofuran4-ones showed less biological activity in contrast to indol-4-ones (mean ranks: 33.92 and 15.08 , respectively). Therefore, benzofuran-4-ones had higher antifungal activity (evaluated at 48 and $72 \mathrm{~h}$ ) in filamentous fungi than indol-4-ones (mean ranks: 5.50 and 11.50) and there was no improvement in the biological activity of any yeast.

\subsection{Statistical Analysis between the Calculated and Experimental MIC Values}

Statistical comparison between the calculated and experimental MIC values was performed using the Mann-Whitney $U$ test only with comparable molecules: 14, 15-1, 15-33 and 15-34. The NICS(0) and NICS(1) of benzofuran-4-ones were calculated and substituted in the equations of indol-4-ones. The summary of the statistical analysis is shown in Table S-4. Even though the equations used to evaluate the calculated antifungal activity were obtained from indole-4-one compounds, the equations fit well to predict the activity of benzofuran-4-ones. The calculated and experimental MIC values were similar in general. The results obtained support the use of NICS in the molecular design of compounds with antifungal activity. 
Table 5. Summary of the MIC values in vitro of 14 and 15 for yeasts and filamentous fungus.

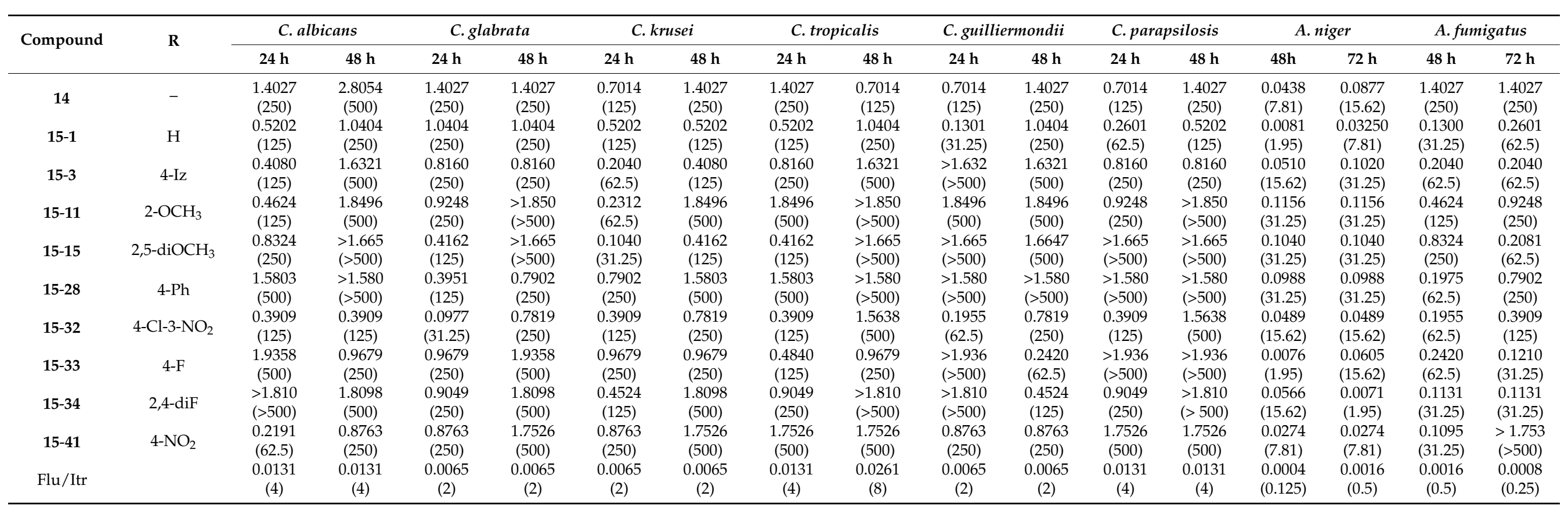

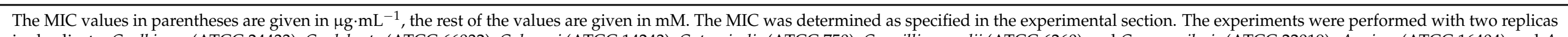

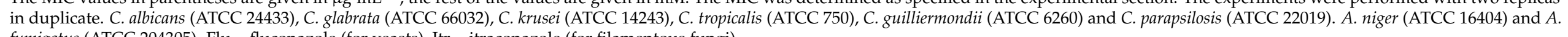
fumigatus (ATCC 204305). Flu = fluconazole (for yeasts), Itr = itraconazole (for filamentous fungi). 
Table 6. Summary of NICS and MIC values in vitro of indol-4-ones and benzofuran-4-ones.

\begin{tabular}{|c|c|c|c|c|c|c|c|c|c|c|c|c|c|c|c|c|}
\hline & \multicolumn{8}{|c|}{ Indol-4-Ones } & \multicolumn{8}{|c|}{ Benzofuran-4-Ones } \\
\hline & \multicolumn{2}{|c|}{6} & \multicolumn{2}{|c|}{$\mathrm{H}$} & \multicolumn{2}{|c|}{$4-\mathrm{F}$} & \multicolumn{2}{|c|}{ 2,4-diF } & \multicolumn{2}{|c|}{14} & \multicolumn{2}{|c|}{$\mathrm{H}$} & \multicolumn{2}{|c|}{$4-\mathrm{F}$} & \multicolumn{2}{|c|}{ 2,4-diF } \\
\hline $\begin{array}{l}\operatorname{NICS}(0) \\
\operatorname{NICS}(1)\end{array}$ & \multicolumn{2}{|c|}{$\begin{array}{c}-10.34 \\
-7.67\end{array}$} & \multicolumn{2}{|c|}{$\begin{array}{l}-9.88 \\
-6.79\end{array}$} & \multicolumn{2}{|c|}{$\begin{array}{c}-10.03 \\
-7.08\end{array}$} & \multicolumn{2}{|c|}{$\begin{array}{c}-10.06 \\
-7.03\end{array}$} & \multicolumn{2}{|c|}{$\begin{array}{l}-8.97 \\
-7.19\end{array}$} & \multicolumn{2}{|c|}{$\begin{array}{l}-8.02 \\
-6.24\end{array}$} & \multicolumn{2}{|c|}{$\begin{array}{l}-8.03 \\
-6.80\end{array}$} & \multicolumn{2}{|c|}{$\begin{array}{l}-8.26 \\
-7.37\end{array}$} \\
\hline & $24 \mathrm{~h}$ & $48 \mathrm{~h}$ & $24 \mathrm{~h}$ & $48 \mathrm{~h}$ & $24 \mathrm{~h}$ & $48 \mathrm{~h}$ & $24 \mathrm{~h}$ & $48 \mathrm{~h}$ & $24 \mathrm{~h}$ & $48 \mathrm{~h}$ & $24 \mathrm{~h}$ & $48 \mathrm{~h}$ & $24 \mathrm{~h}$ & $48 \mathrm{~h}$ & $24 \mathrm{~h}$ & $48 \mathrm{~h}$ \\
\hline C. albicans & $\begin{array}{c}1.4105 \\
(250)\end{array}$ & $\begin{array}{c}2.8210 \\
(500)\end{array}$ & $\begin{array}{c}0.5223 \\
(125)\end{array}$ & $\begin{array}{c}1.0447 \\
(250)\end{array}$ & $\begin{array}{l}0.2429 \\
(62.5)\end{array}$ & $\begin{array}{c}0.9716 \\
(250)\end{array}$ & $\begin{array}{c}0.2270 \\
(62.5)\end{array}$ & $\begin{array}{l}0.9081 \\
(250)\end{array}$ & $\begin{array}{l}1.4027 \\
(250)\end{array}$ & $\begin{array}{c}2.8054 \\
(500)\end{array}$ & $\begin{array}{c}0.5202 \\
(125)\end{array}$ & $\begin{array}{c}1.0404 \\
(250)\end{array}$ & $\begin{array}{c}1.9358 \\
(500)\end{array}$ & $\begin{array}{c}0.9679 \\
(250)\end{array}$ & $\begin{array}{l}>1.810 \\
(>500)\end{array}$ & $\begin{array}{c}1.8098 \\
(500)\end{array}$ \\
\hline C. glabrata & $\begin{array}{c}0.1467 \\
(500)\end{array}$ & $\begin{array}{l}1.9736 \\
(1000)\end{array}$ & $\begin{array}{c}0.5223 \\
(125)\end{array}$ & $\begin{array}{l}4.1787 \\
(1000)\end{array}$ & $\begin{array}{c}0.4858 \\
(125)\end{array}$ & $\begin{array}{c}0.9716 \\
(250)\end{array}$ & $\begin{array}{c}0.4541 \\
(125)\end{array}$ & $\begin{array}{c}0.9081 \\
(250)\end{array}$ & $\begin{array}{c}1.4027 \\
(250)\end{array}$ & $\begin{array}{c}1.4027 \\
(250)\end{array}$ & $\begin{array}{c}1.0404 \\
(250)\end{array}$ & $\begin{array}{c}1.0404 \\
(250)\end{array}$ & $\begin{array}{c}0.9676 \\
(250)\end{array}$ & $\begin{array}{c}1.9358 \\
(500)\end{array}$ & $\begin{array}{c}0.9049 \\
(250)\end{array}$ & $\begin{array}{c}1.8098 \\
(500)\end{array}$ \\
\hline C. krusei & $\begin{array}{c}0.2304 \\
(500)\end{array}$ & $\begin{array}{l}1.8428 \\
(1000)\end{array}$ & $\begin{array}{c}0.5223 \\
(125)\end{array}$ & $\begin{array}{l}1.0445 \\
(250)\end{array}$ & $\begin{array}{c}0.2429 \\
(62.5)\end{array}$ & $\begin{array}{c}0.4858 \\
(125)\end{array}$ & $\begin{array}{l}0.2270 \\
(62.5)\end{array}$ & $\begin{array}{l}0.4541 \\
(125)\end{array}$ & $\begin{array}{l}0.7014 \\
(125)\end{array}$ & $\begin{array}{l}1.4027 \\
(250)\end{array}$ & $\begin{array}{c}0.5202 \\
(125)\end{array}$ & $\begin{array}{c}0.5202 \\
(125)\end{array}$ & $\begin{array}{c}0.9679 \\
(250)\end{array}$ & $\begin{array}{c}0.9679 \\
(250)\end{array}$ & $\begin{array}{c}0.4524 \\
(125)\end{array}$ & $\begin{array}{c}1.8098 \\
(500)\end{array}$ \\
\hline C. tropicalis & $\begin{array}{c}0.2304 \\
(250)\end{array}$ & $\begin{array}{l}1.8428 \\
(1000)\end{array}$ & $\begin{array}{l}0.2612 \\
(62.5)\end{array}$ & $\begin{array}{c}0.5253 \\
(125)\end{array}$ & $\begin{array}{l}0.1214 \\
(31.25)\end{array}$ & $\begin{array}{l}0.2429 \\
(62.5)\end{array}$ & $\begin{array}{l}0.1135 \\
(31.25)\end{array}$ & $\begin{array}{l}0.2270 \\
(62.5)\end{array}$ & $\begin{array}{c}1.4027 \\
(250)\end{array}$ & $\begin{array}{c}0.7014 \\
(125)\end{array}$ & $\begin{array}{c}0.5202 \\
(125)\end{array}$ & $\begin{array}{l}1.0404 \\
(250)\end{array}$ & $\begin{array}{c}0.4840 \\
(125)\end{array}$ & $\begin{array}{c}0.9679 \\
(250)\end{array}$ & $\begin{array}{c}0.9049 \\
(250)\end{array}$ & $\begin{array}{l}>1.810 \\
(>500)\end{array}$ \\
\hline C. guilliermondii & $\begin{array}{c}0.4321 \\
(250)\end{array}$ & $\begin{array}{c}0.8641 \\
(500)\end{array}$ & $\begin{array}{c}0.2612 \\
(62.5)\end{array}$ & $\begin{array}{c}0.5223 \\
(125)\end{array}$ & $\begin{array}{l}0.1214 \\
(31.25)\end{array}$ & $\begin{array}{c}0.2429 \\
(62.5)\end{array}$ & $\begin{array}{l}0.1135 \\
(31.25)\end{array}$ & $\begin{array}{c}0.2270 \\
(62.5)\end{array}$ & $\begin{array}{c}0.7014 \\
(125)\end{array}$ & $\begin{array}{c}1.4027 \\
(250)\end{array}$ & $\begin{array}{l}0.1301 \\
(31.25)\end{array}$ & $\begin{array}{c}1.0404 \\
(250)\end{array}$ & $\begin{array}{l}>1.936 \\
(>500)\end{array}$ & $\begin{array}{l}0.2420 \\
(62.5)\end{array}$ & $\begin{array}{l}>1.810 \\
(>500)\end{array}$ & $\begin{array}{c}0.4524 \\
(125)\end{array}$ \\
\hline \multirow[t]{2}{*}{ C. parapsilosis } & $\begin{array}{c}0.4344 \\
(8)\end{array}$ & $\begin{array}{l}0.8687 \\
(62.5)\end{array}$ & $\begin{array}{c}0.0669 \\
(16)\end{array}$ & $\begin{array}{l}1.0447 \\
(250)\end{array}$ & $\begin{array}{c}0.0622 \\
(16)\end{array}$ & $\begin{array}{c}0.2410 \\
(62)\end{array}$ & $\begin{array}{c}0.0581 \\
(16)\end{array}$ & $\begin{array}{c}0.9081 \\
(250)\end{array}$ & $\begin{array}{c}0.7014 \\
(125)\end{array}$ & $\begin{array}{c}1.4027 \\
(250)\end{array}$ & $\begin{array}{l}0.2601 \\
(62.5)\end{array}$ & $\begin{array}{c}0.5202 \\
(125)\end{array}$ & $\begin{array}{l}>1.936 \\
(>500)\end{array}$ & $\begin{array}{l}>1.936 \\
(>500)\end{array}$ & $\begin{array}{c}0.9049 \\
(250)\end{array}$ & $\begin{array}{l}>1.810 \\
(>500)\end{array}$ \\
\hline & $48 \mathrm{~h}$ & $72 \mathrm{~h}$ & $48 \mathrm{~h}$ & $72 \mathrm{~h}$ & $48 \mathrm{~h}$ & $72 \mathrm{~h}$ & $48 \mathrm{~h}$ & $72 \mathrm{~h}$ & $48 \mathrm{~h}$ & $72 \mathrm{~h}$ & $48 \mathrm{~h}$ & $72 \mathrm{~h}$ & $48 \mathrm{~h}$ & $72 \mathrm{~h}$ & $48 \mathrm{~h}$ & $72 \mathrm{~h}$ \\
\hline A. niger & $\begin{array}{c}0.4344 \\
(125)\end{array}$ & $\begin{array}{c}0.8687 \\
(250)\end{array}$ & $\begin{array}{c}>1.0447 \\
(>250)\end{array}$ & $\begin{array}{c}>1.0447 \\
(>250)\end{array}$ & $\begin{array}{c}>0.9716 \\
(>250)\end{array}$ & $\begin{array}{c}>0.9716 \\
(>250)\end{array}$ & $\begin{array}{c}>0.9081 \\
(>250)\end{array}$ & $\begin{array}{c}>0.9081 \\
(>250)\end{array}$ & $\begin{array}{l}0.0438 \\
(7.81)\end{array}$ & $\begin{array}{l}0.0877 \\
(15.62)\end{array}$ & $\begin{array}{l}0.0081 \\
(1.95)\end{array}$ & $\begin{array}{c}0.03250 \\
(7.81)\end{array}$ & $\begin{array}{l}0.0076 \\
(1.95)\end{array}$ & $\begin{array}{l}0.0605 \\
(15.62)\end{array}$ & $\begin{array}{l}0.0566 \\
(15.62)\end{array}$ & $\begin{array}{l}0.0071 \\
(1.95)\end{array}$ \\
\hline A. fumigatus & $\begin{array}{c}0.3879 \\
(125)\end{array}$ & $\begin{array}{c}0.7758 \\
(250)\end{array}$ & $\begin{array}{c}1.0447 \\
(250)\end{array}$ & $\begin{array}{c}1.0447 \\
(250)\end{array}$ & $\begin{array}{c}>0.9716 \\
(>250)\end{array}$ & $\begin{array}{c}>0.9716 \\
(>250)\end{array}$ & $\begin{array}{c}>0.9081 \\
(>250)\end{array}$ & $\begin{array}{c}>0.9081 \\
(>250)\end{array}$ & $\begin{array}{c}1.4027 \\
(250)\end{array}$ & $\begin{array}{c}1.4027 \\
(250)\end{array}$ & $\begin{array}{l}0.1300 \\
(31.25)\end{array}$ & $\begin{array}{l}0.2601 \\
(62.5)\end{array}$ & $\begin{array}{l}0.2420 \\
(62.5)\end{array}$ & $\begin{array}{l}0.1210 \\
(31.25)\end{array}$ & $\begin{array}{l}0.1131 \\
(31.25)\end{array}$ & $\begin{array}{l}0.1131 \\
(31.25)\end{array}$ \\
\hline
\end{tabular}

The NICS values are given in $\mathrm{ppm}$, the MIC values in parentheses are given in $\mu \mathrm{g} \cdot \mathrm{mL}^{-1}$, the rest of the values are given in $\mathrm{mM}$. 


\section{Materials and Methods}

\subsection{Computational Details}

The geometries of the molecules 6, 7a-g, 8a-g [5], 14 and 15-1 to 15-43 were fully optimized at the gas phase and at the B3LYP/6-311 + G $(d, p)$ level of theory $[26,27]$. Scheme 4 shows the optimized geometries of the main compounds. The B3LYP functional was proved to be valid previously in the calculation of NICS of pyrrole and pyridine [28], the chemical reactivity of oxazole [29] and imidazole [30] and the basicity of phenol [31]. The calculations were performed using the Gaussian 09 program package [32]. Minimum energy structures were obtained and verified by all positive frequencies for each molecule.

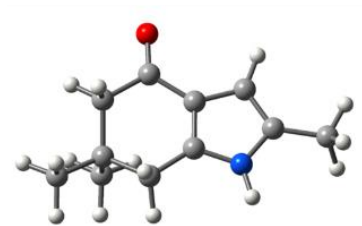

6

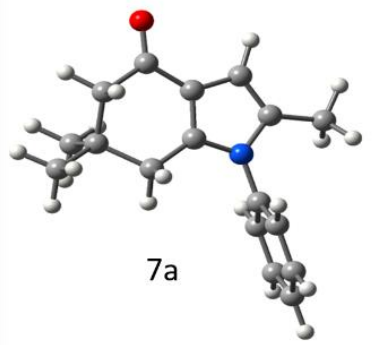

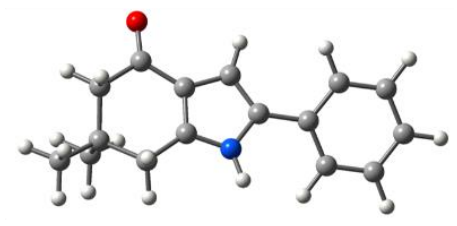

$8 a$

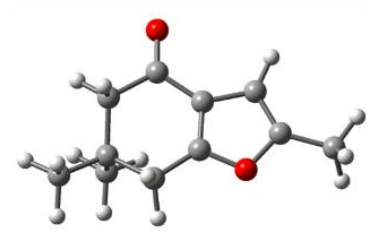

14

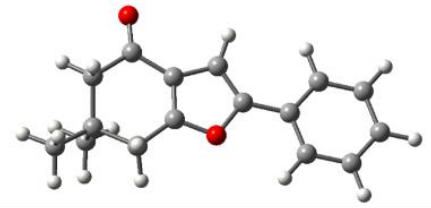

$15-1$

Scheme 4. Optimized geometries of the main compounds.

The NICS(0) and NICS(1) values were obtained from the isotropic chemical shift revealed by the gauge-independent atomic orbital (GIAO) calculations of the geometric center at the five-membered ring of each structure at and $1 \AA$ above the molecular plane, respectively $[2,3]$. Scheme 5 shows the ghost atoms locations to calculate NICS(0) and NICS(1).

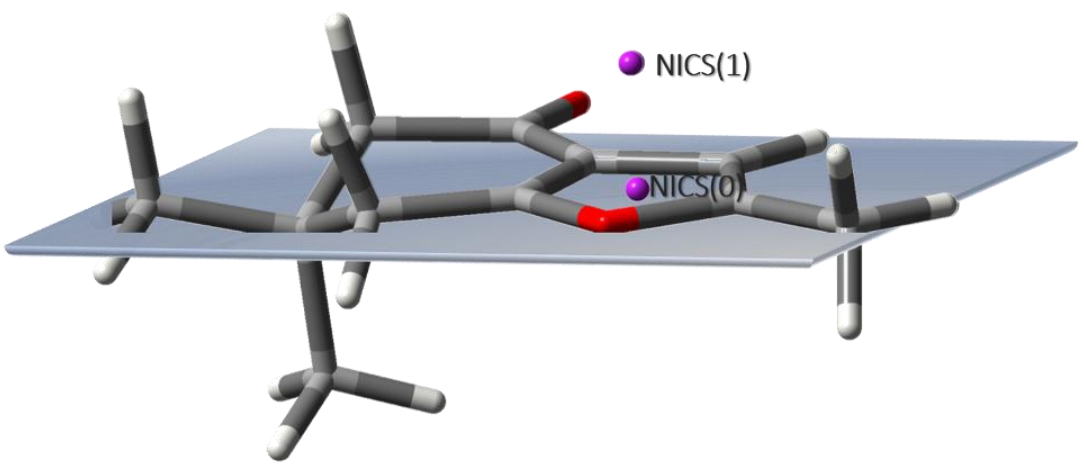

Scheme 5. Ghost atoms locations to obtain the NICS(0) and NICS(1) computed at and above the ring center of the five-membered ring.

\subsection{Structure-Activity Relationship (SAR) Statistical Procedure}

The MIC values of a set of indol-4-ones versus NICS(0) and NICS(1) values at 24 and $48 \mathrm{~h}$ for yeasts and 48 and $72 \mathrm{~h}$ for filamentous fungi were plotted (Table S1). Simple regression analysis for each plot was performed and Pearson and significant one coefficients were obtained using the SAS software [33]. The $p<0.05$ value was considered significant for this study. The best equations and the classification of the indol-4-ones used by us were used to predict the antifungal activity of the new compounds. 


\subsection{Synthesis of Benzofuran-4-ones}

All the reagents and solvents used were reagent grade (Sigma-Aldrich Co. St. Louis, MO, USA). Monitoring of reactions was performed by means of thin-layer chromatography (Sigma-Aldrich Inc. St. Luis, MO, USA) using aluminum and silica gel 60 support chromatofolios, with an $\mathrm{F}_{254}$ indicator from Merck.

A medium-resolution column chromatography column was used to separate the reaction mixtures using silica gel as the stationary phase and a mixture of hexane ethyl acetate as the mobile phase. Synthesis intermediaries and final products were characterized by means of infrared spectroscopy with the Thermo Nicolet Nexus 470 FT-IT E.S.P. equipment (Thermo Nicolet Co. Madison, WI. USA), ${ }^{1} \mathrm{H}$ nuclear magnetic resonance $\left({ }^{1} \mathrm{H}-\mathrm{NMR}\right)$ and ${ }^{13} \mathrm{C}$ nuclear magnetic resonance $\left({ }^{13} \mathrm{C}-\mathrm{NMR}\right)$ with the Variant Gemini $200 \mathrm{MHz}$ and $50 \mathrm{MHz}$, respectively) (Varian associates, Palo Alto, CA. USA) and Jeol (300 MHz and $70 \mathrm{MHz}$, respectively) equipment (Jeol USA, Inc, Peabody, MA. USA) utilizing dimethylsulfoxide $\left(\right.$ DMSO- $\left.\mathrm{d}_{6}\right)$ as the solvent. Chemical shifts are expressed with $\delta \mathrm{ppm}$ values relative to tetramethylsilane (TMS) used as the internal standard ( $\mathrm{s}=$ singlet, $\mathrm{d}=$ doublet, $\mathrm{t}=$ triplet, $\mathrm{q}=$ quadruplet, sext $=$ sextet and $\mathrm{m}=$ multiplet). Coupling constants $(\mathrm{J})$ are shown in Hertz $(\mathrm{Hz})$.

5,5-dimethyl-2-(2-oxopropyl)cyclohexane-1,3-dione (12)

A mixture of $14 \mathrm{mmol}$ of sodium ethoxide, $2 \mathrm{~g}$ (14 mmol) of 5,5-dimethylciclohexane1,3-dione and $1.33 \mathrm{~mL}$ ( $14 \mathrm{mmol}$ ) of chloroacetone in $20 \mathrm{~mL}$ of ethanol was refluxed for $30 \mathrm{~min}$ and then letting cold. Sodium chloride was separated by filtration and their filtrate was vacuum-concentrated. The residual oil was dissolved in a 1:1 mixture of chloroform $(20 \mathrm{~mL})$ and $10 \%$ sodium hydroxide $(20 \mathrm{~mL})$. The aqueous phase was separated and then extracted with chloroform $(20 \mathrm{~mL})$; this aqueous phase was cooled in an ice bath, acidified with chloride acid, and the organic phase was extracted with chloroform $(3 \times 20 \mathrm{~mL})$. The organic extracts were dried with anhydrous sodium sulfate and filtered, the resulting solution was concentrated by evaporation in vacuum. Recrystallization was performed in acetone, and compound 12 was obtained as colorless crystals, yield: $80 \%$, mp: $133-135^{\circ} \mathrm{C}$. ${ }^{1} \mathrm{H}-\mathrm{NMR}\left(200 \mathrm{MHz}, \mathrm{DMSO}-\mathrm{d}_{6}\right) \delta=0.99(\mathrm{~s}, 6 \mathrm{H}), 1.98(\mathrm{~s}, 3 \mathrm{H}), 2.22(\mathrm{~s}, 4 \mathrm{H}), 3.16(\mathrm{~s}, 1 \mathrm{H})$, $3.33(\mathrm{~s}, 1 \mathrm{H}), 10.62$ (s, 1H). EI-MS: $m / z$ (\%): 196 (M+, 51), 154 (89), 125 (24), 98 (100), 55 (45). IR (KBr): $\lambda=2962,2931,1720,1645,1155,1064 \mathrm{~cm}^{-1}$.

General procedure for the synthesis of 2-(2-(R)-2-oxoethyl)-5,5-dimethylcyclohexane1,3-diones (13s)

A suspension with dimedone 11 (1 eq), bromoacetophenones 10 (1 eq) and anhydrous $\mathrm{K}_{2} \mathrm{CO}_{3}(1.8 \mathrm{eq})$ in chloroform was agitated to room temperature for $12 \mathrm{~h}$. Then, the mixture was filtered. The salts were dissolved in water and the filtered solutions were acidulated with concentrated $\mathrm{HCl}$. The precipitate was separated by filtration and washed with water.

5,5-dimethyl-2-(2-oxo-2-phenylethyl)cyclohexane-1,3-dione (13-1)

White dust, yield: $39.5 \%$, m.p.: $136-138{ }^{\circ} \mathrm{C} .{ }^{1} \mathrm{H}-\mathrm{NMR}\left(200 \mathrm{MHz}, \mathrm{DMSO}-\mathrm{d}_{6}\right) \delta=0.97$ (s, 6H), $2.10(\mathrm{~s}, 4 \mathrm{H}), 3.79(\mathrm{~s}, 2 \mathrm{H}), 7.44-7.63(\mathrm{~m}, 3 \mathrm{H}), 7.90-7.95(\mathrm{~m}, 2 \mathrm{H}), 10.96(\mathrm{~s}, 1 \mathrm{H})$. EI-MS: $m / z$ (\%): 258 (M+, 11), 140 (30), 105 (34), 83 (100), 54 (55). IR (KBr): $\lambda=2960,2869,2680$, 2630, 2576, 2532, 1617, 1577, 1529, 1471, 1349, 14305, 1226, $1145 \mathrm{~cm}^{-1}$.

2-(2-(4-(1H-pyrrol-1-yl)phenyl)-2-oxoethyl)-5,5-dimethylcyclohexane-1,3-dione (13-3)

Brown dust, yield: $54 \%$, m.p.: $60-62{ }^{\circ} \mathrm{C} .{ }^{13} \mathrm{C}-\mathrm{NMR}$ (101 MHz, DMSO) $\delta=190.15$, $179.58,176.08,175.18,99.30,49.99,33.33,32.71,31.94,29.55,28.97$. IR (KBr): $\lambda=2952,2670$, $1683,1609,1374,1243,1204,1039,764 \mathrm{~cm}^{-1}$.

2-(2-(2-methoxyphenyl)-2-oxoethyl)-5,5-dimethylcyclohexane-1,3-dione (13-11)

White dust, yield: $65 \%$, m.p.: $151{ }^{\circ} \mathrm{C} .{ }^{1} \mathrm{H}-\mathrm{NMR}(300 \mathrm{MHz}, \mathrm{DMSO}) \delta=7.51(\mathrm{~d}$, $J=1.8 \mathrm{~Hz}, 1 \mathrm{H}), 7.47(\mathrm{~d}, J=7.5 \mathrm{~Hz}, 1 \mathrm{H}), 7.12(\mathrm{~d}, J=7.9 \mathrm{~Hz}, 1 \mathrm{H}), 7.02-6.94(\mathrm{~m}, 1 \mathrm{H})$, $3.37(\mathrm{~s}, 3 \mathrm{H}), 2.20(\mathrm{~d}, 4 \mathrm{H}), 0.98(\mathrm{~d}, 6 \mathrm{H}) .{ }^{13} \mathrm{C}-\mathrm{NMR}(101 \mathrm{MHz}, \mathrm{DMSO}) \delta=199.40,157.89$, 132.96, 129.51, 128.42, 120.23, 112.11, 108.65, 102.44, 55.67, 37.22, 32.13, 27.93. TOFMS: $m / z(\%): 289(\mathrm{M}+, 99.2), 271(0.8), 181$ (7.5), $152(0.8), 135$ (1.5). IR (KBr): $\lambda=3178,2958,2663$, $1666,1594,2595,1467,1394,1255,1201,1155,1045,761 \mathrm{~cm}^{-1}$. 
White dust, yield: $51 \%$, m.p.: $143-145{ }^{\circ} \mathrm{C} .{ }^{1} \mathrm{H}-\mathrm{NMR}(400 \mathrm{MHz}, \mathrm{DMSO}) \delta=7.07$ (d, $J=1.8 \mathrm{~Hz}, 2 \mathrm{H}), 7.03-7.00(\mathrm{~m}, 1 \mathrm{H}), 3.81(\mathrm{~s}, 3 \mathrm{H}), 3.36(\mathrm{~s}, 6 \mathrm{H}), 2.21(\mathrm{~s}, 4 \mathrm{H}), 0.98(\mathrm{~s}, 6 \mathrm{H}) .{ }^{13} \mathrm{C}-$ NMR (101 MHz, DMSO) $\delta=198.86,152.78,152.25,128.73,118.64,113.74,108.60,56.20$, 55.50, 37.16, 31.76, 27.90. IR (KBr): $\lambda=3161,2952,2835,2652,1661,1504,1491,1390,1330$, $1278,1248,1217,1050,817,752 \mathrm{~cm}^{-1}$.

2-(2-([1,1'-biphenyl]-4-yl)-2-oxoethyl)-5,5-dimethylcyclohexane-1,3-dione (13-28)

Yellow dust, yield: 48\%, m.p.: 158-160 ${ }^{\circ} \mathrm{C}$. EI-MS: $m / z(\%): 334(\mathrm{M}+, 5.6), 319(0.9)$, 181 (99.9), 152 (27.1), 151 (3.7), 55 (4.7), 55 (12.2), 41 (13.1), 29 (3.7). IR (KBr): $\lambda=2952,2670$, $1683,1609,1374,1243,1204,1039,764 \mathrm{~cm}^{-1}$.

2-(2-(4-chloro-3-nitrophenyl)-2-oxoethyl)-5,5-dimethylcyclohexane-1,3-dione (13-32)

White dust, yield: $66 \%$, m.p.: $171-173{ }^{\circ} \mathrm{C} .{ }^{1} \mathrm{H}-\mathrm{NMR}(400 \mathrm{MHz}, \mathrm{DMSO}) \delta=10.81$ (s, $1 \mathrm{H}), 8.50(\mathrm{~d}, J=2.0 \mathrm{~Hz}, 1 \mathrm{H}), 8.18(\mathrm{dd}, J=8.4,2.1 \mathrm{~Hz}, 1 \mathrm{H}), 7.94-7.90(\mathrm{~m}, 1 \mathrm{H}), 3.82(\mathrm{~s}, 2 \mathrm{H})$, $2.25(\mathrm{~s}, 4 \mathrm{H}), 0.99(\mathrm{~s}, 6 \mathrm{H}) .{ }^{13} \mathrm{C}-\mathrm{NMR}(101 \mathrm{MHz}, \mathrm{DMSO}) \delta=195.51,147.70,136.59,132.51$, $132.13,128.94,124.68,107.69,79.26-79.07,32.89,31.86,27.82$. IR (KBr): $\lambda=3091,2952,2926$, $2656,1696,1596,1560,1534,1387,1356,1226,821 \mathrm{~cm}^{-1}$.

2-(2-(4-fluorophenyl)-2-oxoethyl)-5,5-dimethylcyclohexane-1,3-dione (13-33)

White dust, yield: 59\%, m.p.: $96{ }^{\circ} \mathrm{C} .{ }^{1} \mathrm{H}-\mathrm{NMR}(400 \mathrm{MHz}, \mathrm{DMSO}) \delta=8.05-7.99(\mathrm{~m}$, 2H), 7.36-7.28 (m, 2H), $3.34(\mathrm{~s}, 3 \mathrm{H}), 2.46-2.04(\mathrm{~m}, 4 \mathrm{H}), 1.02(\mathrm{~s}, 6 \mathrm{H}) .{ }^{13} \mathrm{C}-\mathrm{NMR}(101 \mathrm{MHz}$, DMSO) $\delta=196.05,165.99,163.49,133.66,130.71,115.63,115.41,108.03,32.47,31.86,27.89$. IR (KBr): $\lambda=2960,2923,1670,1597,1385,1255,1223,1165,840,671 \mathrm{~cm}^{-1}$.

2-[2-(2,4-difluorophenyl)-2-oxoethyl]-5,5-dimethylcyclohexane-1,3-dione (13-34)

Yellow dust, yield: 73\%, m.p.: $138{ }^{\circ} \mathrm{C} .{ }^{1} \mathrm{H}-\mathrm{NMR}\left(200 \mathrm{MHz}, \mathrm{DMSO}-\mathrm{d}_{6}\right) \delta=0.97(\mathrm{~s}, 6 \mathrm{H})$, $2.22(\mathrm{~s}, 4 \mathrm{H}), 3.68(\mathrm{~d}, 2 \mathrm{H}, J=2.4 \mathrm{~Hz}), 7.18(\mathrm{ddd}, 1 \mathrm{H}, J=7.2,9.6$ and $0.8 \mathrm{~Hz}), 7.37(\mathrm{ddd}, 1 \mathrm{H}$, $J=11.45,9.3$ and $2.6 \mathrm{~Hz}), 7.81(\mathrm{ddd}, 1 \mathrm{H}, J=16,7.6$ and $1.8 \mathrm{~Hz}), 10.61(\mathrm{~s}, 1 \mathrm{H}) .{ }^{13} \mathrm{C}-\mathrm{NMR}$ $(50 \mathrm{MHz}, \mathrm{DMSO}-\mathrm{d} 6) \delta=27.8,31.8,36.3,44.6,104.9,107.7,112.1,122.7,132.2,158.8,162.0$, 163.9, 167.03, 172.9, 194.7. EI-MS: $m / z(\%): 294(\mathrm{M}+, 46), 153$ (30), 141(100), 97 (24), 83 (14), 55 (8). IR (KBr): $\lambda=3077,2964,2892,2657,1695,1608,1577,1243,1199,1147,1099$, $1039 \mathrm{~cm}^{-1}$.

5,5-dimethyl-2-(2-(4-nitrophenyl)-2-oxoethyl)cyclohexane-1,3-dione (13-41)

Orange liquid, yield: 28\%. ${ }^{1} \mathrm{H}-\mathrm{NMR}(400 \mathrm{MHz}, \mathrm{DMSO}) \delta=8.34-8.29(\mathrm{~m}, 2 \mathrm{H})$, 8.17-8.11 (m, 2H), $3.41(\mathrm{t}, J=103.4 \mathrm{~Hz}, 3 \mathrm{H}), 2.25(\mathrm{~s}, 4 \mathrm{H}), 1.00(\mathrm{~s}, 6 \mathrm{H})$. TOFMS: $m / z(\%)$ : $304(\mathrm{M}+, 99.2), 290(0.8), 155$ (0.8). ${ }^{13} \mathrm{C}-\mathrm{NMR}(101 \mathrm{MHz}, \mathrm{DMSO}) \delta=196.98,144.11,139.01$, $135.78,129.08,128.41,126.85,108.16,32.51,31.88,27.92 . \mathrm{IR}(\mathrm{KBr}): \lambda=2970,2939,1717,1578$, $1382,1356,1256,1217,1156,1064,608 \mathrm{~cm}^{-1}$.

General procedure for synthesis of compounds 14 and $15 \mathrm{~s}$

Trimethylsilyl chloride ( 1 eq) was added to a suspension with carbonyl compounds (4 eq, $50 \mathrm{mg}$ ) dissolved in $\mathrm{MeOH}(300 \mathrm{uL})$. The resulting suspension was collocated in a microwave oven with the following conditions: $90^{\circ} \mathrm{C}, 250 \mathrm{~W}, 290 \mathrm{psi}, 8 \mathrm{~min}$ [25]. The mixture was left to cool to room temperature and the solid was filtered and washed with hexane. The resultant mixture was purified with column chromatography using silica gel in a gradient of 3-20\% AcOE:hexane as the eluent. The compounds were obtained after vacuum fraction evaporation.

2,6,6-trimethyl-6,7-dihydrobenzofuran-4(5H)-one (14)

Yellow liquid, yield: 72\%. ${ }^{1} \mathrm{H}-\mathrm{NMR}\left(200 \mathrm{MHz}, \mathrm{DMSO}-\mathrm{d}_{6}\right) \delta=1.06(\mathrm{~s}, 6 \mathrm{H}), 2.22(\mathrm{~s}$, $3 \mathrm{H}), 2.27$ (s, $2 \mathrm{H}), 2.62$ (s, $2 \mathrm{H}), 6.16$ (s, $1 \mathrm{H})$. EI-MS: $m / z$ (\%): 178 (M+, 65), 121 (92), 93 (100), 66 (7), 42 (13). IR (KBr): $\lambda=2961,2874,1680,1605,1584,1433,1387,1346,1302,1248,1227$, $1184,1115,1033,930 \mathrm{~cm}^{-1}$.

6,6-dimethyl-2-phenyl-6,7-dihydrobenzofuran-4(5H)-one (15-1)

Colorless crystals, yield: 67\%, m.p.: $103-105{ }^{\circ} \mathrm{C} .{ }^{1} \mathrm{H}-\mathrm{NMR}\left(200 \mathrm{MHz}, \mathrm{DMSO}-\mathrm{d}_{6}\right)$ $\delta=1.15(\mathrm{~s}, 6 \mathrm{H}), 2.37(\mathrm{~s}, 2 \mathrm{H}), 2.74(\mathrm{~s}, 2 \mathrm{H}), 6.77$ (s. 1H), 7.15-7.7 (m, 5H). EI-MS: $m / z(\%): 240$ (M+, 62), 185 (31), 184 (88), 157 (10), 156 (75), 128 (13), 105 (100), 77 (28), 51 (9), 43 (4), 41 (8). IR (KBr): $\lambda=2950,2870,1665,1440,1220,755,680 \mathrm{~cm}^{-1}$.

2-(4-(1H-imidazol-1-yl)phenyl)-6,6-dimethyl-6,7-dihydrobenzofuran-4(5H)-one (15-3) 
Light brown dust, yield: 50\%, m.p.: 88-90 ${ }^{\circ} \mathrm{C}$. IR (KBr): $\lambda=2956,2927,1657,1609$, $1375,1226,1153,1016,825 \mathrm{~cm}^{-1}$.

2-(2-metoxyphenyl)-6,6-dimethyl-6,7-dihydrobenzofuran-4(5H)-one (15-11)

White dust, yield: $57 \%$, m.p.: $106-108{ }^{\circ} \mathrm{C} .{ }^{1} \mathrm{H}-\mathrm{NMR}(400 \mathrm{MHz}, \mathrm{DMSO}) \delta=7.74(\mathrm{dd}$, $J=7.8,1.7 \mathrm{~Hz}, 1 \mathrm{H}), 7.33(\mathrm{ddd}, J=8.9,7.4,1.7 \mathrm{~Hz}, 1 \mathrm{H}), 7.14(\mathrm{~d}, J=7.8 \mathrm{~Hz}, 1 \mathrm{H}), 7.05(\mathrm{td}$, $J=7.7,1.0 \mathrm{~Hz}, 1 \mathrm{H}), 7.01(\mathrm{~s}, 1 \mathrm{H}), 2.87(\mathrm{~s}, 2 \mathrm{H}), 2.36(\mathrm{~s}, 2 \mathrm{H}), 1.09(\mathrm{~s}, 6 \mathrm{H}) .{ }^{13} \mathrm{C}-\mathrm{NMR}(101 \mathrm{MHz}$, DMSO) $\delta=193.17,165.27,155.16,150.07,129.18,125.24,121.01,120.63,117.74,111.74$, $105.13,55.56,51.37,36.34,34.94,27.98$. IR (KBr): $\lambda=3149,2956,2870,1685,1595,1491,1442$, $1253,1118,1012,752,671 \mathrm{~cm}^{-1}$.

2-(2,5-dimethoxyphenyl)-6,6-dimethyl-6,7-dihydrobenzofuran-4(5H)-one (15-15)

Beige dust, yield: $56 \%$, m.p.: $124-125{ }^{\circ} \mathrm{C} .{ }^{1} \mathrm{H}-\mathrm{NMR}(400 \mathrm{MHz}, \mathrm{DMSO}) \delta=7.25(\mathrm{~d}$, $J=3.1 \mathrm{~Hz}, 1 \mathrm{H}), 7.08(\mathrm{~d}, J=9.0 \mathrm{~Hz}, 1 \mathrm{H}), 7.03(\mathrm{~s}, 1 \mathrm{H}), 6.91(\mathrm{dd}, J=9.0,3.1 \mathrm{~Hz}, 1 \mathrm{H}), 3.87$ $(\mathrm{s}, 3 \mathrm{H}), 3.76(\mathrm{~s}, 3 \mathrm{H}), 2.88(\mathrm{~s}, 2 \mathrm{H}), 2.36(\mathrm{~s}, 2 \mathrm{H}), 1.09(\mathrm{~s}, 6 \mathrm{H}) .{ }^{13} \mathrm{C}-\mathrm{NMR}(101 \mathrm{MHz}, \mathrm{DMSO})$ $\delta=193.12,165.34,153.10,149.85,149.48,121.05,118.28,114.15,112.95,110.39,105.47,55.91$, $55.52,36.35,34.94,30.67,27.97$. IR (KBr): $\lambda=2962,2871,2643,1685,1611,1446,1403,1282$, $1240,1049,1110,1018,800,733 \mathrm{~cm}^{-1}$.

2-([1,1'-biphenyl]-4-yl)-6,6-dimethyl-6,7-dihydrobenzofuran-4(5H)-one (15-28)

Beige crystals, yield: $83 \%$, m.p.: $176{ }^{\circ} \mathrm{C} .{ }^{1} \mathrm{H}-\mathrm{NMR}(400 \mathrm{MHz}, \mathrm{DMSO}) \delta=7.86-7.82(\mathrm{~m}$, 2H), 7.78-7.70 (m, 4H), 7.51-7.45 (m, 2H), 7.41-7.35 (m, 1H), $7.23(\mathrm{~s}, 1 \mathrm{H}), 2.91(\mathrm{~s}, 2 \mathrm{H}), 2.39$ (s, 2H), 1.11 (s, 6H). IR (KBr): $\lambda=2952,1670,1448,1396,1213,1117,761 \mathrm{~cm}^{-1}$.

2-(4-chloro-3-nitrophenyl)-6,6-dimethyl-6,7-dihydrobenzofuran-4(5H)-one (15-32)

Light yellow crystals, yield: $85 \%$, m.p.: $198-199{ }^{\circ} \mathrm{C} .{ }^{1} \mathrm{H}-\mathrm{NMR}(400 \mathrm{MHz}, \mathrm{DMSO})$ $\delta=8.40(\mathrm{~d}, J=2.1 \mathrm{~Hz}, 1 \mathrm{H}), 8.05(\mathrm{dd}, J=8.5,2.2 \mathrm{~Hz}, 1 \mathrm{H}), 7.85(\mathrm{~d}, J=8.5 \mathrm{~Hz}, 1 \mathrm{H}), 7.48(\mathrm{~s}$, $1 \mathrm{H}), 2.91(\mathrm{~s}, 2 \mathrm{H}), 2.39(\mathrm{~s}, 2 \mathrm{H}), 1.10(\mathrm{~s}, 6 \mathrm{H}) .{ }^{13} \mathrm{C}-\mathrm{NMR}(101 \mathrm{MHz}, \mathrm{DMSO}) \delta=192.96,167.26$, $150.49,148.25,132.31,129.63,128.25,123.57,121.35,120.12,104.63,51.32,36.35,34.92,27.91$. IR (KBr): $\lambda=3100,2952,2917,2869,1674,1569,1535,1443,1339,1226,830,743,630 \mathrm{~cm}^{-1}$.

2-(4-fluorophenyl)-6,6-dimethyl-6,7-dihydrobenzofuran-4(5H)-one (15-33)

White crystals, yield: $71 \%$, m.p.: $118^{\circ} \mathrm{C} .{ }^{1} \mathrm{H}-\mathrm{NMR}(400 \mathrm{MHz}, \mathrm{DMSO}) \delta=7.81-7.76(\mathrm{~m}, 2 \mathrm{H})$, 7.30-7.25 (m, 2H), $7.15(\mathrm{~s}, 1 \mathrm{H}), 2.87(\mathrm{~s}, 2 \mathrm{H}), 2.36(\mathrm{~s}, 2 \mathrm{H}), 1.09(\mathrm{~s}, 6 \mathrm{H}) .{ }^{13} \mathrm{C}-\mathrm{NMR}(101 \mathrm{MHz}$, DMSO) $\delta=193.07,166.09,163.01,160.57,152.78,125.93,121.11,116.08,115.86,101.24,51.35$, 36.36, 34.92, 27.95. IR (KBr): $\lambda=3091,2948,2926,2869,1665,1495,1591,1222,1161,1126$, $635,826 \mathrm{~cm}^{-1}$.

2-(2,4-difluorophenyl)-6,6-dimethyl-6,7-dihydrobenzofuran-4(5H)-one (15-34)

Colorless crystals, yield: 59\%, m.p.: $155-158{ }^{\circ} \mathrm{C} .{ }^{1} \mathrm{H}-\mathrm{NMR}\left(300 \mathrm{MHz}, \mathrm{DMSO}-\mathrm{d}_{6}\right)$ $\delta=1.08(\mathrm{~s}, 6 \mathrm{H}), 2.37(\mathrm{~s}, 2 \mathrm{H}), 2.81(\mathrm{~s}, 2 \mathrm{H}), 6.90(\mathrm{~d}, 1 \mathrm{H}, J=3.3 \mathrm{~Hz}), 7.20(\mathrm{ddd}, 1 \mathrm{H}, \mathrm{J}=3 \mathrm{~Hz})$, 7.40 (ddd, $\left.1 \mathrm{H}, J=2.7,10.5 \mathrm{~Hz}), 7.82(\mathrm{ddd}, 1 \mathrm{H}, J=6.6,10 \mathrm{~Hz}) .{ }^{13} \mathrm{C}-\mathrm{NMR}\left(75 \mathrm{MHz}, \mathrm{DMSO}_{6}\right)_{6}\right)$ $\delta=27.8,34.8,36.2,51.2,104.7,104.9,112.2,114.1,120.9,127.4,147.0,156.3,159.8,163.3$, 166.1, 192.8. EI-MS: $m / z(\%): 276(\mathrm{M}+, 71), 220$ (66), 192 (60), 164 (10), 141 (100), 113 (11), 63 (4), 41 (3). IR (KBr): $\lambda=3066,2956,2904,2871,1648,1513,1465,1413,1224,1120,1045,863$, $794 \mathrm{~cm}^{-1}$.

6-6-dimethyl-2-(4-nitrophenyl)-6,7-dihydrobenzofuran-4(5H)-one (15-41)

Light yellow crystals, yield: $42 \%$, m.p.: $180{ }^{\circ} \mathrm{C} .{ }^{1} \mathrm{H}-\mathrm{NMR}(400 \mathrm{MHz}, \mathrm{DMSO})$ $\delta=8.30-8.26(\mathrm{~m}, 2 \mathrm{H}), 8.03-7.98(\mathrm{~m}, 2 \mathrm{H}), 7.55(\mathrm{~s}, 1 \mathrm{H}), 2.93(\mathrm{~s}, 2 \mathrm{H}), 2.40(\mathrm{~s}, 2 \mathrm{H}), 1.10(\mathrm{~s}$, 6H). ${ }^{13} \mathrm{C}-\mathrm{NMR}(101 \mathrm{MHz}, \mathrm{DMSO}) \delta=192.96,167.83,151.56,146.34,135.18,124.41,121.53$, $105.74,51.33,36.40,34.90,30.68,27.92$. IR (KBr): $\lambda=3101,2960,2960,2929,2866,1672,1574$, $1535,1444,1338,1223,1128,1041,835 \mathrm{~cm}^{-1}$.

\subsection{Antifungal Activity}

Compounds 14 and 15 were evaluated for antifungal activity in vitro using commercial antifungals such as fluconazole for yeasts and itraconazole for fungi. Activities are reported in the minimum inhibitory concentration (MIC) values using the serial microdilution method on 96-well plates. The following reference strains were purchased from the American Type Culture Collection (ATCC): Candida albicans ATCC 24433, C. glabrata ATCC 66032, C. guilliermondii ATCC 6260, C. krusei ATCC 14243, C. tropicalis ATCC 750, A. niger 
ATCC 16404 and A. fumigatus ATCC 204305. The MIC values were determined according to the M27-S4 method of the Clinical Laboratory Standards Institute for yeasts [34] and the M38 method for fungi [35]. The RPMI-1740 (Sigma) culture medium buffered with $0.165 \mathrm{M}$ of HEPES (Sigma) was used. The MIC values were defined as the minimum concentration that inhibits growth of $\geq 50 \%$ Candida spp. and \% Aspergillus spp. in comparison to the controls. The compounds were dissolved in ethanol and serially diluted in the growth medium. The yeasts were incubated to $35-37^{\circ} \mathrm{C}$ and the MIC values were measured at 24 and $48 \mathrm{~h}$; the fungi were incubated to $35-37^{\circ} \mathrm{C}$ and measured at 48 and $72 \mathrm{~h}$.

\section{Conclusions}

The statement of Wu et al. that aromaticity may have considerable implications for molecular design was applied to obtain compounds with antifungal activity. The antifungal activity of two series of indol-4-ones was related to the aromaticity of the five-membered ring (evaluated with the NICS(0) and NICS(1) of the pyrrole ring) and the enolate and keto resonance structures; when aromaticity increased, the antifungal activity decreased for series I and increased for series II. A bioisosteric change [36,37] in indol-4-ones was made substituting the nitrogen atom with an oxygen atom in the five-membered ring to obtain benzofuran-4-ones. Ten benzofuran-4-ones were synthesized and tested against eight human pathogenic fungi. The equations obtained through simple linear regression using the NICS values and the antifungal activity predicted the experimental biological activity of benzofuran-4-ones; the biological activity calculated was statistically the same as the one obtained experimentally. Benzofuran-4-ones had a higher antifungal activity in filamentous fungi than indol-4-ones. The highest activity was for A. niger $(1.95 \mu \mathrm{g} \cdot \mathrm{mL})$ which is around 128 times higher than the activity observed with indol-4-ones. The results support the statement of Wu et al. and show the importance of aromaticity in the molecular design of compounds with antifungal activity. The advantages of the use of NICS(0) and NICS(1) as criteria of aromaticity are that they are easy and economical to compute and at least in this model proposed provide reliable results. We are working on the study of the interactions between indole-4-ones and benzofuran-4-ones with their biological targets.

Supplementary Materials: The following are available online at https:/ / www.mdpi.com/article/ 10.3390/molecules26165078/s1, Tables S1 and S2 show the equations obtained by simple linear regression of antifungal activity (MIC) vs. aromaticity (NICS), Tables S3 and S4 show the summary of the Mann-Whitney $U$ test. Atomic coordinates for compounds 14, 15-1, 15-3, 15-11, 15-15, 15-28, 15-32, 15-33, 15-34 and 15-41.

Author Contributions: Conceptualization, M.M.G.-C. and F.M.; methodology, M.d.l.Á.Z.-M., A.R., R.G.-C., L.E.O.-F., P.d.C.N.-M. and R.M.; formal analysis, M.d.l.Á.Z.-M., M.M.G.-C., F.M., A.R., R.G.C., P.d.C.N.-M. and R.M.; investigation, M.d.l.Á.Z.-M., M.M.G.-C., F.M. and A.R.; writing-original draft preparation, M.d.l.Á.Z.-M.; writing—review and editing, M.M.G.-C., F.M. and A.R. All authors have read and agreed to the published version of the manuscript.

Funding: This research received no external funding.

Institutional Review Board Statement: Not applicable.

Informed Consent Statement: Not applicable.

Data Availability Statement: The data presented in this study are available in the supplementary materials.

Acknowledgments: We thank CONACYT (grants 389176 and 291061) for student financial support for M.A. Zermeño-Macías, as well as Rosa María Chávez Santos, Rubén Omar Torres-Ochioa, E. García, E. Bonilla, H. Rios and J. Perez of Instituto de Química, UNAM, for technical assistance.

Conflicts of Interest: The authors declare no conflict of interest.

Sample Availability: Samples of the compounds 14, 15-1, 15-3, 15-11, 15-15, 15-28, 15-32, 15-33, 15-34 and 15-41 are available from the authors. 


\section{References}

1. Pauling, L.; Wheland, G.W. The Nature of the Chemical Bond. V. The Quantum-Mechanical Calculation of the Resonance Energy of Benzene and Naphthalene and the Hydrocarbon Free Radicals. J. Chem. Phys. 1933, 1, 362. [CrossRef]

2. Schleyer, P.V.R.; Maerker, C.; Dransfeld, A.; Jiao, H.; van Eikema Hommes, N.J. Nucleus-Independent Chemical Shifts: A Simple and Efficient Aromaticity Probe. J. Am. Chem. Soc. 1996, 118, 6317-6318. [CrossRef] [PubMed]

3. Chen, Z.; Wannere, C.S.; Corminboeuf, C.; Puchta, R.; Schleyer, P.V.R. Nucleus-Independent Chemical Shifts (NICS) as an Aromaticity Criterion. Chem. Rev. 2005, 105, 3842-3888. [CrossRef]

4. Ramirez-Tagle, R.; Higgins, U.B.O. NICS: A Possible New Criterion to Evaluate the Structure-Antioxidant Activity Relationship of Phenolic Compound. Oxid. Commun. 2011, 520, 516-520.

5. Wu, J.I.; Jackson, J.E.; Schleyer, P.V.R. Reciprocal Hydrogen Bonding - Aromaticity Relationships. J. Am. Chem. Soc. 2014, 136, 13526-13529. [CrossRef]

6. Evstigneev, M.P. Physicochemical Mechanisms of Synergistic Biological Action of Combinations of Aromatic Heterocyclic Compounds. Org. Chem. Int. 2013, 2013, 1-10. [CrossRef]

7. Pianalto, K.; Alspaugh, J. New Horizons in Antifungal Therapy. J. Fungi 2016, 2, 1-24. [CrossRef] [PubMed]

8. Ghannoum, M.A.; Rice, L.B. Antifungal Agents: Mode of Action, Mechanisms of Resistance, and Correlation of These Mechanisms with Bacterial Resistance. Clin. Microbiol. Rev. 1999, 12, 501-517. [CrossRef] [PubMed]

9. Vandeputte, P.; Ferrari, S.; Coste, A.T. Antifungal Resistance and New Strategies to Control Fungal Infections. Int. J. Microbiol. 2012, 2012, 1-26. [CrossRef] [PubMed]

10. Campoy, S.; Adrio, J.L. Antifungals. Biochem. Pharmacol. 2016, 133, 86-96. [CrossRef]

11. Che, X.; Sheng, C.; Wang, W.; Cao, Y.; Xu, Y.; Ji, H.; Dong, G.; Miao, Z.; Yao, J.; Zhang, W. New Azoles with Potent Antifungal Activity: Design, Synthesis and Molecular Docking. Eur. J. Med. Chem. 2009, 44, 4218-4226. [CrossRef] [PubMed]

12. Borate, H.B.; Maujan, S.R.; Sawargave, S.P.; Chandavarkar, M.A.; Vaiude, S.R.; Joshi, V.A.; Wakharkar, R.D.; Iyer, R.; Kelkar, R.G.; Chavan, S.P.; et al. Fluconazole Analogues Containing 2H-1,4-Benzothiazin-3(4H)-One or 2H-1,4-Benzoxazin-3(4H)-One Moieties, a Novel Class of Anti-Candida Agents. Bioorganic Med. Chem. Lett. 2010, 20, 722-725. [CrossRef] [PubMed]

13. Bari, S.B.; Haswani, N.G. Design, Synthesis and Molecular Docking Study of Thienopyrimidin-4(3H)-Thiones as Antifungal Agents. J. Saudi Chem. Soc. 2014, 21, S264-S274. [CrossRef]

14. Jain, K.S.; Khedkar, V.M.; Arya, N.; Rane, P.V.; Chaskar, P.K.; Coutinho, E.C. Design, Synthesis \& Evaluation of Condensed 2H-4-Arylaminopyrimidines as Novel Antifungal Agents. Eur. J. Med. Chem. 2014, 77, 166-175. [CrossRef]

15. Buragohain, P.; Surineni, N.; Barua, N.C.; Bhuyan, P.D.; Boruah, P.; Borah, J.C.; Laisharm, S.; Moirangthem, D.S. Synthesis of a Novel Series of Fluoroarene Derivatives of Artemisinin as Potent Antifungal and Anticancer Agent. Bioorganic Med. Chem. Lett. 2015, 25, 3338-3341. [CrossRef]

16. Shah, J.J.; Khedkar, V.; Coutinho, E.C.; Mohanraj, K. Design, Synthesis and Evaluation of Benzotriazole Derivatives as Novel Antifungal Agents. Bioorg. Med. Chem. Lett. 2015, 25, 3730-3737. [CrossRef]

17. Chandrika, N.T.; Shrestha, S.K.; Ngo, H.X.; Garneau-Tsodikova, S. Synthesis and Investigation of Novel Benzimidazole Derivatives as Antifungal Agents. Bioorg. Med. Chem. 2016, 24, 3680-3686. [CrossRef]

18. Hemalatha, K.; Madhumitha, G.; Ravi, L.; Khanna, V.G.; Al-Dhabi, N.A.; Arasu, M.V. Binding Mode of Dihydroquinazolinones with Lysozyme and Its Antifungal Activity against Aspergillus Species. J. Photochem. Photobiol. B Biol. 2016, 161, 71-79. [CrossRef]

19. Wilson, P.R.; Yusuf, S. In silico design, docking, synthesis and antimicrobial evaluation of 2, 5-disubstituted 1,3,4-oxadiazole derivatives. Int. J. Pharm. Sci. Res. 2016, 7, 2074-2082. [CrossRef]

20. Singh, V.K.; Rishishwar, P.; Bhardwaj, P.; Alok, S. Benzotrizole: A Heterocyclic Molecule with Diversified Pharmacological Activities. Int. J. Pharm. Sci. Res. 2017, 8, 446-456. [CrossRef]

21. Doğan, İ.S.; Saraç, S.; Sari, S.; Kart, D.; Eşsiz Gőkhan, Ş.; Vural, İ.; Dalkara, S. New Azole Derivatives Showing Antimicrobial Effects and Their Mechanism of Antifungal Activity by Molecular Modeling Studies. Eur. J. Med. Chem. 2017, 130, 124-138. [CrossRef]

22. González-Chávez, R.; Martínez, R.; Torre-Bouscoulet, M.E.; Gallo, M.; González-Chávez, M.M. De Novo Design of NonCoordinating Indolones as Potential Inhibitors for Lanosterol 14- $\alpha$-Demethylase (CYP51). Chem. Pharm. Bull. 2014, 62, 16-24. [CrossRef]

23. Zermeño-Macías, M.A.; González-Chávez, M.M.; Méndez, F.; González-Chávez, R.; Richaud, A. Theoretical Reactivity Study of Indol-4-Ones and Their Correlation with Antifungal Activity. Molecules 2017, 22, 1-16. [CrossRef]

24. Horner, K.E.; Karadakov, P.B. Chemical Bonding and Aromaticity in Furan, Pyrrole, and Thiophene: A Magn. Shielding Study. 2013, 78, 8037-8043. [CrossRef]

25. Goncalves, S.; Wagner, A.; Mioskowski, C.; Baati, R. Microwave-Assisted Synthesis of 4-Keto-4,5,6,7-Tetrahydrobenzofurans. Tetrahedron Lett. 2009, 50, 274-276. [CrossRef]

26. Becke, A.D. Density-Functional Thermochemistry. III. The Role of Exact Exchange. J. Chem. Phys. 1993, 98, 5648-5652. [CrossRef]

27. Lee, C.; Yang, W.; Parr, R.G. Development of the Colle-Salvetti Correlation-Energy Formula into a Functional of the Electron Density. Phys. Rev. B Condens. Matter Mater. Phys. 1988, 37, 785-789. [CrossRef] [PubMed]

28. Richaud, A.; Barba-Behrens, N.; Méndez, F. Chemical Reactivity of the Imidazole: A Semblance of Pyridine and Pyrrole? Org. Lett. 2011, 13, 972-975. [CrossRef] 
29. Suárez-Moreno, G.V.; González-Zamora, E.; Méndez, F. Oxazole as an Electron-Deficient Diene in the Diels-Alder Reaction. Org. Lett. 2011, 13, 6358-6361. [CrossRef] [PubMed]

30. Richaud, A.; Méndez, F.; Barba-Behrens, N.; Florian, P.; Medina-Campos, O.M.; Pedraza-Chaverri, J. Electrophilic Modulation of the Superoxide Anion Radical Scavenging Ability of Copper(II) Complexes with 4-Methyl Imidazole. J. Phys. Chem. A 2021, 125, 2394-2401. [CrossRef] [PubMed]

31. Richaud, A.; Méndez, F.; Alonso, J.A. Elimination vs Substitution Reaction. A Dichotomy between Brønsted-Lowry and Lewis Basicity. Org. Lett 2015, 17, 767-769. [CrossRef]

32. Frisch, M.J.; Trucks, G.W.; Schlegel, H.B.; Scuseria, G.E.; Robb, M.A.; Cheeseman, J.R.; Scalmani, G.; Barone, V.; Mennucci, B.; Petersson, G.A.; et al. Gaussian 09, Revision D.01; Gaussian. Inc.: Wallingford, CT, USA, 2009.

33. SAS Software, V. 8.0; SAS Institute Inc.: Cary, NC, USA, 1999.

34. CLSI. Reference Method for Broth Dilution Antifungal Susceptibility Testing of Yeast; Fourth Informational Supplement; CLSI document M27-S4; Clinical and Laboratory Standards Institute: Wayne, PA, USA, 2012.

35. CLSI. Reference Method for Broth Dilution Antifungal Susceptibiliity Testing of Filamentous Fungi, 3rd ed.; CLSI standard M38; Clinical and Laboratory Standards Institute: Wayne, PA, USA, 2017.

36. Sheng, C.; Che, X.; Wang, W.; Wang, S.; Cao, Y.; Miao, Z.; Yao, J.; Zhang, W. Design and Synthesis of Novel Triazole Antifungal Derivatives by Structure-Based Bioisosterism. Eur. J. Med. Chem. 2011, 46, 5276-5282. [CrossRef] [PubMed]

37. Jiang, Z.; Wang, Y.; Wang, W.; Wang, S.; Xu, B.; Fan, G.; Dong, G.; Liu, Y.; Yao, J.; Miao, Z.; et al. Discovery of Highly Potent Potent Triazole Antifungal Derivatives by Heterocycle-Benzene Bioisosteric Replacement. Eur. J. Med. Chem. 2013, 64, 16-22. [CrossRef] [PubMed] 